\title{
24. ORIGIN OF AUTHIGENIC CARBONATES IN EOCENE TO QUATERNARY SEDIMENTS FROM THE ARCTIC OCEAN AND NORWEGIAN-GREENLAND SEA ${ }^{1}$
}

\author{
Nancy Chow, ${ }^{2}$ Sadoon Morad, ${ }^{3}$ and Ihsan S. Al-Aasm ${ }^{4}$
}

\begin{abstract}
Authigenic carbonates occur in thin layers, nodules, and burrows in fine-grained siliciclastic sediments of middle Eocene to Quaternary age that were recovered from the Arctic Ocean and Norwegian-Greenland Sea during Leg 151. At Site 913 (East Greenland Margin), concentrically zoned microspherules and rhombohedrons of ferroan rhodochrosite and manganoan siderite, $20-600 \mu \mathrm{m}$ in diameter, are the main authigenic carbonates in the sedimentary succession. They grew displacively within the host clays and silts, and have locally coalesced to form aggregates. At Sites 909 (Fram Strait) and 911 (Yermak Plateau), very fine to fine-crystalline siderite, enriched in $\mathrm{Ca}$ and/or $\mathrm{Mg}$, is the predominant carbonate in the sedimentary succession. It occurs as interparticle cement, disseminated crystals, and rounded intraclasts in host clays, silts, and muds. Minor micritic or radialfibrous calcite and dolomite were also found at these three sites. Most of these carbonates are interpreted to have precipitated at shallow-burial depths during early diagenesis.

All authigenic carbonates (rhodochrosite, siderite, and calcite) from Site 913 are strongly enriched in ${ }^{12} \mathrm{C}\left(\delta^{13} \mathrm{C}=-22.9\right.$ to $-13.8 \%$ ) and show decreasing $\delta^{13} \mathrm{C}$ values with depth below the seafloor. This evidence, along with authigenic pyrite found in microspherule cores, suggests that dissolved carbon was derived from the oxidation of marine organic matter in the bacterial sulfate-reduction zone and during the early stages of methanogenesis. However, low organic matter content and headspace methane concentrations suggest additional derivation of dissolved carbon from thermogenic methane. The very low $\delta^{18} \mathrm{O}$ values $(-11.8 \%$ ) for rhodochrosite and the close association with barite in voids and fractures suggest rhodochrosite precipitation from $\mathrm{Mn}$-charged, hydrothermal fluids, possibly related to volcanic activity associated with seafloor spreading.

The $\delta^{13} \mathrm{C}$ values of most siderites from Site 909 are close to $-6 \%$, which suggests an origin in the Fe-reduction, suboxic zone, possibly only centimeters or decimeters below the seafloor. However, minor occurrences of siderite with very low $\delta^{13} \mathrm{C}$ values $(-21.8 \%$ ), along with their close association with authigenic pyrite, indicate additional derivation of dissolved carbon from bacterial sulfate-reduction and the early stages of methanogenesis. The importance of anaerobic microbial processes is further corroborated by the moderate to high organic matter content and headspace methane concentration at Site 909 . The range of $\delta^{18} \mathrm{O}$ values for siderite from Sites 909 and $911(-10.3$ to $+5.0 \%$ c) appears to be related to both increasing burial temperatures and interaction between labile volcaniclastic sediment and marine pore waters.
\end{abstract}

\section{INTRODUCTION}

Various types of authigenic carbonates with diverse elemental and isotopic compositions have been recovered from Cenozoic deepsea sediments from many drilling sites by the Deep Sea Drilling Project and Ocean Drilling Programs (DSDP and ODP) (e.g., Pisciotto and Mahoney, 1981; Kelts and McKenzie, 1982; Matsumoto and Matsuhisa, 1985). However, complex authigenic carbonates, particularly those dominated by different generations of $\mathrm{Mn}$ - and $\mathrm{Fe}$-rich phases, have been reported only sporadically (e.g., von Rad and Botz, 1987; Bohrmann and Thiede, 1989; Henrich, 1989; Matsumoto, 1992). These complex carbonates can provide important clues as to the nature of the diagenetic environment, particularly the origin, composition, and temperature of the precipitating fluids, and the alteration of organic matter and noncarbonate constituents.

Middle Eocene to Quaternary sediments recovered at Sites 909 and 911 in the Arctic Ocean and at Site 913 in the eastern Greenland Basin during ODP Leg 151 contain carbonate-rich layers (laminae and thin beds) and nodules distributed sporadically throughout the sedimentary successions. These layers and nodules are variable in

Thiede, J., Myhre, A.M., Firth, J.V., Johnson, G.L., and Ruddiman, W.F. (Eds.), 1996. Proc, ODP, Sci. Results, 151: College Station, TX (Ocean Drilling Program).

${ }^{2}$ Department of Geological Sciences, University of Manitoba, Winnipeg, Manitoba R3T 2N2, Canada. n_chow@umanitoba.ca

'Institute of Earth Sciences, Uppsala University, S-752 36 Uppsala, Sweden.

${ }^{4}$ Department of Earth Sciences, University of Windsor, Windsor, Ontario N9B 3P4, Canada. their size, shape, and induration, and they contain authigenic siderite and rhodochrosite, with subordinate amounts of calcite and dolomite. They are the first-reported authigenic carbonates from the Arctic Ocean and Norwegian-Greenland Sea, north of $75^{\circ} \mathrm{N}$ latitude; previous work had documented authigenic carbonates from more southerly locations in the Norwegian Sea and Labrador Sea (Henrich, 1989; Bohrmann and Thiede, 1989). The purpose of this paper is to document the occurrence, mineralogy, textural relationships, and geochemistry of the authigenic carbonates from Sites 909,911 , and 913 , and to provide preliminary interpretations for the origin of these carbonates, particularly the timing of and processes responsible for carbonate precipitation and pore water evolution. Future work awaits more detailed analyses of the carbonates, pore waters, and host sediments.

\section{GEOLOGIC SETTING}

During the course of Leg 151, data were collected from seven sites in the Arctic Ocean and Norwegian-Greenland Sea (Myhre and Thiede, 1995). Authigenic carbonates were identified and sampled at five of these sites (Site 907 on the Iceland Plateau; Sites 908 and 909 in the Fram Strait; Site 911 on the Yermak Plateau; and Site 913 along the East Greenland Margin), but only Sites 909, 911, and 913 provided sufficient samples for a detailed study (Fig. 1). The geologic settings of these three sites are summarized below and in Figure 2 (refer to Shipboard Scientific Party, 1995b, 1995c, 1995d; Thiede et al., 1995).

Site $909\left(78^{\circ} 35^{\prime} \mathrm{N}, 3^{\circ} 4^{\prime} \mathrm{E}\right)$ is located on an abyssal terrace, known as the Greenland-Spitsbergen Sill, located just northeast of the Hov- 


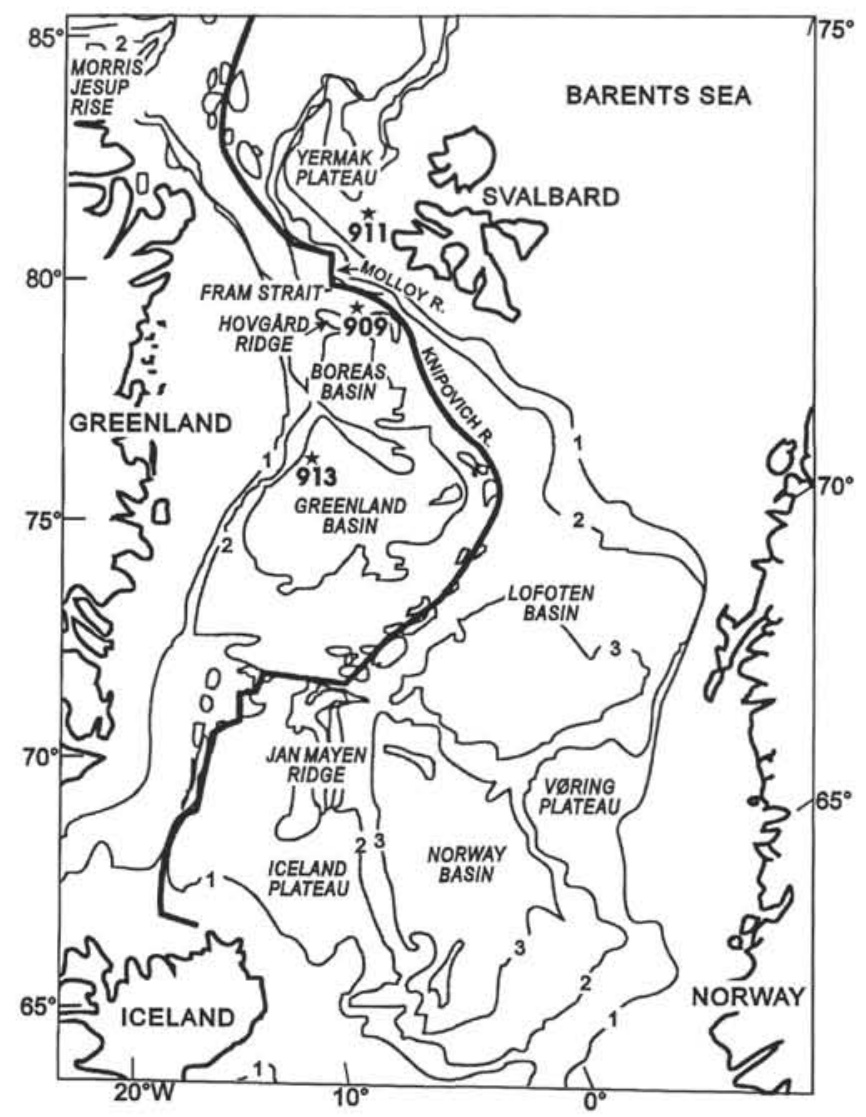

Figure 1. Simplified bathymetric map (in $\mathrm{km}$ ) of the Norwegian-Greenland Sea and Arctic Ocean, showing the locations of Sites 909, 911, and 913 (modified from Myhre and Thiede, 1995).

gård Ridge in the Fram Strait between Greenland and Svalbard. The Greenland-Spitsbergen Sill is dominated by light to moderately bioturbated, hemipelagic sediments, along with varying amounts of sand and dropstones. Lithologic Unit I ( $0-248.8$ meters below the seafloor [mbsf]; Pliocene to Quaternary) consists of silty clays and clayey silts interbedded with silty muds, clayey muds, and clays (refer to Shipboard Scientific Party [1995a] for sediment classification). Calcareous microfossils are absent below $50 \mathrm{mbsf}$, indicating deposition below the carbonate compensation depth. Dropstones consist of sedimentary, basaltic, and metamorphic rock fragments. Lithologic Unit II (248.8-518.3 mbsf; Miocene to Pliocene) is composed of mottled to laminated, silty clays, and carbonate-rich clays and silty clays. Lithologic Unit III (518.3-1061.8 mbsf; Miocene to Oligocene) consists of silty clays, clayey silts, and clayey and silty muds, along with some carbonate-rich layers. The lower $140 \mathrm{~m}$ is distinguished by meter-thick intervals of slumped sediment, showing small-scale folding, rip-up clasts, and pinched and tilted layers.

Site $911\left(80^{\circ} 28^{\prime} \mathrm{N}, 8^{\circ} 13^{\prime} \mathrm{E}\right)$ is situated on the upper slope of the southeastern part of the Yermak Plateau, a marginal plateau attached to the continental margin of Svalbard and bounded to the west by a divergent plate boundary that has been active since the early Tertiary (Crane et al., 1982). The Pliocene to Quaternary sedimentary succession penetrated at Site 911 is predominantly clayey silts and silty clays with minor interbeds of silty muds and clayey muds, all showing slight to intense bioturbation. The upper $380 \mathrm{~m}$ (Subunit IA) is characterized by abundant dropstones.

Site $913\left(75^{\circ} 29^{\prime} \mathrm{N}, 6^{\circ} 59^{\prime} \mathrm{W}\right)$ is located on the eastern, lower slope of the deep Greenland Basin. Poor core recovery and spot coring pre- clude a detailed lithologic description and sampling of the upper 423 $\mathrm{m}$ of the succession. Lithologic Unit I (0-143.8 mbsf; Miocene? to Quaternary) consists predominantly of clayey and silty muds, characterized by abundant dropstones. The uppermost $3 \mathrm{~m}$ (Subunit IA) also contains interbeds of foraminifer-rich clays and silty muds. Lithologic Unit II (143.8-378.7 mbsf; Miocene? to Quaternary) is clays, clayey silts, and silty muds, and lithologic Unit III (378.7-674.1 mbsf; Eocene to Miocene) is predominantly massive and laminated silty clays and clays. Biosiliceous sediment of green, blue, and purple coloration distinguish the middle part of Unit III (Subunit IIIB, $462.0-500.3 \mathrm{mbsf}$ ), and carbonate clays and claystones occur sporadically throughout the lower $174 \mathrm{~m}$ of the unit (Subunit IIIC). Lithologic Unit IV (674.1-770.3 mbsf; undetermined age) consists mainly of laminated silty clays and clays that are thickly interbedded with massive silty clays, and silty and sandy muds. Slump structures occur between 693.0 and 721.9 mbsf.

\section{SAMPLES AND METHODS}

A total of 162 representative samples of carbonate-rich layers and nodules from Sites 909, 911, and 913 were collected during Leg 151, based on cursory visual identification. Organic matter and carbonate contents of all samples were approximated by weight loss on ignition to $450^{\circ} \mathrm{C}$ for $1 \mathrm{hr}$ and $1000^{\circ} \mathrm{C}$ for $1 \mathrm{hr}$, respectively (Dean, 1974). Xray diffraction (XRD) analysis of all samples was performed using a Phillips PW1710 diffractometer with Ni-filtered, $\mathrm{CuK} \alpha$ radiation of $30 \mathrm{kV} / 15 \mathrm{~mA}$. Quartz, which was present in most samples, was used as an internal standard correction of the $d(104)$ spacing of carbonates. The relative proportions of the different carbonates were estimated from the peak intensities for the $d(104)$ reflections between $29.5^{\circ}$ and $32.5^{\circ}(2 \theta)$.

Thirty samples were sufficiently well indurated to permit impregnation with blue epoxy and preparation of polished thin sections. These sections were examined by plane-polarized light, cathodoluminescence, and epi-fluorescence microscopy, using a Nikon Optiphot microscope mounted with a Technosyn cold-cathodoluminescence unit (operating at $20 \mathrm{kV}$ and $400 \mathrm{~mA}$ ) and an episcopic-fluorescence attachment with a blue-excitation filter block (480-nm main wavelength). Cathodoluminescence microscopy proved to be of little use, as the authigenic carbonates in all samples are nonluminescent.

The polished thin sections were then carbon coated and subjected to electron microprobe analysis using a Cameca Camebax SX-50, equipped with three crystal spectrometers and a backscattered electron (BSE) detector. The operating conditions during analyses were an acceleration voltage of $15 \mathrm{kV}$, a measured beam current of $9 \mathrm{nA}$, and a beam diameter of $1 \mu \mathrm{m}$. Values were reported in mol\% carbonate and only analyses totaling between 98 and $102 \mathrm{~mol} \%$ were considered. Based on counting statistics, the detection limits are estimated to be better than $50 \mathrm{ppm}$ for all the elements measured. The standards used were wollastonite $(\mathrm{Ca}), \mathrm{MgO}(\mathrm{Mg}), \mathrm{MnTiO}_{3}(\mathrm{Mn})$, hematite $(\mathrm{Fe})$, and strontianite $(\mathrm{Sr})$, and the counting time was $10 \mathrm{~s}$.

Carbon and oxygen isotope analyses of 34 selected samples were performed using the methods of McCrea (1950). Powdered carbonate samples were reacted with $100 \%$ phosphoric acid at $25^{\circ} \mathrm{C}$ for about 4 $\mathrm{hr}$ for calcite, $50^{\circ} \mathrm{C}$ for about $4 \mathrm{hr}$ for dolomite, and 5 days for siderite. Separation of the $\mathrm{CO}_{2}$ from different carbonate phases in multicarbonate samples was done by differential chemical leaching methods of Al-Aasm et al. (1990). The collected $\mathrm{CO}_{2}$ gas for each carbonate fraction was analyzed on a SIRA-12 mass spectrometer. The phosphoric acid fractionation factors used were 1.01025 for calcite at $25^{\circ} \mathrm{C}$ (Friedman and O'Neil, 1977), 1.01065 for dolomite, 1.01012 for rhodochrosite at $25^{\circ} \mathrm{C}$ (Friedman and O'Neil, 1977), and 1.009082 for siderite at $50^{\circ} \mathrm{C}$ (Rosenbaum and Sheppard, 1986). Precision $(1 \sigma)$ was monitored through daily analysis of the NBS-20 calcite standard and was better than $0.1 \%$ for both $\delta^{13} \mathrm{C}$ and $\delta^{18} \mathrm{O}$. Inter- 


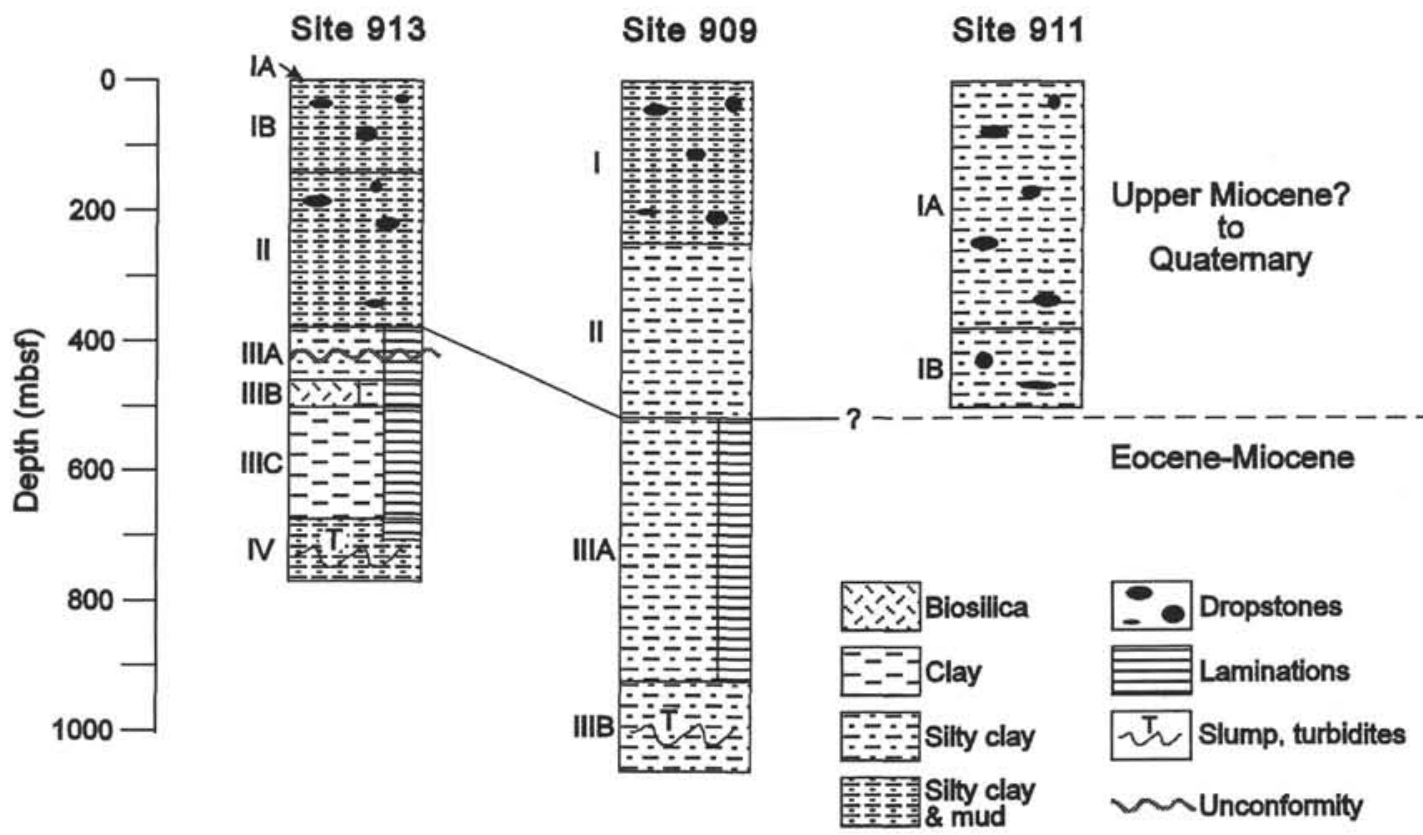

Figure 2. Summary of lithostratigraphic units at Sites 909, 911, and 913 (modified from Thiede et al., 1995). At each of these sites, lithologic Unit I typically represents "ice-house" (glacial) facies, Unit II is the transitional (cooling) facies, and Units III and IV represent "warm-house"(preglacial) facies.

stitial water samples from Sites 909,911 , and 913 were collected during $\operatorname{Leg} 151$, but $\delta^{18} \mathrm{O}$ data were not available at the time of this study.

\section{OCCURRENCE AND DISTRIBUTION OF AUTHIGENIC CARBONATES}

\section{Site 909}

Authigenic carbonates occur in (1) poorly to well-indurated laminae and thin beds (herein referred to as layers), some of which may be nodules or lenses that are not recognizable because of the small diameter of the core; (2) small, poorly indurated nodules; (3) burrow structures; and (4) slump structures. They are characteristically olive gray to dark gray, which readily distinguishes them from the adjacent, darker colored, siliciclastic sediment.

Carbonate-rich layers, up to $9 \mathrm{~cm}$ thick, occur sporadically in Units/Subunits I, II, IIIA, and IIIB. These layers are typically poorly indurated in the upper $200 \mathrm{~m}$, becoming progressively more consolidated with depth. They typically have planar boundaries, but some layers have a slightly "lumpy" shape, apparently caused by differential compaction (Fig. 3). They may be either massive, irregularly laminated, or bioturbated with locally identifiable Planolites-like burrows. Bottom contacts are sharp or gradational and top contacts are gradational. In Subunit IIIB, bioturbated, laminated beds are punctuated by slump structures, as described previously, that are partially composed of carbonates (Fig. 4).

Poorly indurated, carbonate-rich nodules, $1-3 \mathrm{~cm}$ in size, appear to be rare in Subunit IIIB. The nodules are irregularly shaped and tend to be elongated subparallel to bedding. They are massive to irregularly laminated and have sharp boundaries with surrounding sediment. This sediment shows drape structures resulting from differential compaction around the nodules. Burrow structures in Unit II and Subunit IIIA are commonly preferentially composed of poorly consolidated carbonates (Fig. 5). Identifiable structures include Planolites, Teichichnus, and Zoophycos.

Pyrite and $\mathrm{Fe}$ monosulfides are associated with the authigenic carbonates and adjacent siliciclastic sediments in Unit I to Subunit IIIB.

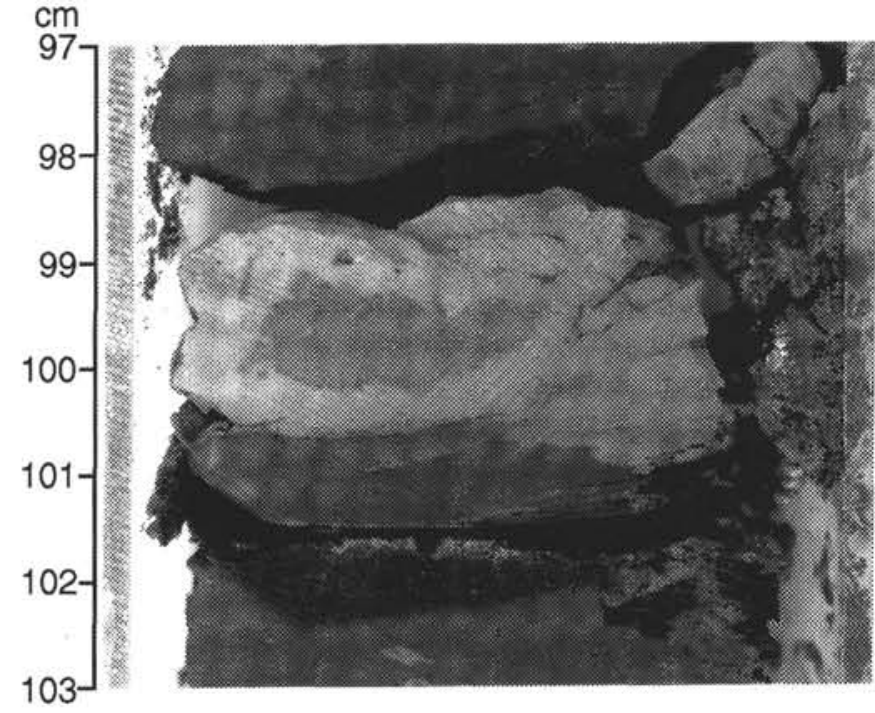

Figure 3. Well-indurated, "lumpy", siderite-rich nodule (light gray in photograph; the darker area is due to a wet surface) in silty clay. Core photograph of Sample 151-909C-62R-5, 97-103 cm.

These sulfides occur as $\mathrm{cm}$-size concretions and in diffuse patches and burrow structures (Fig. 5).

\section{Site 911}

Subunits IA and IB contain dark gray to pale olive thin beds and irregularly shaped patches and nodules of $\mathrm{cm}$-size that are rich in authigenic carbonates. Carbonate beds and patches are poorly indurated, commonly bioturbated, and have gradational contacts with the adjacent siliciclastic sediment. Identifiable burrows include Zoophycos and Planolites. Carbonate nodules are well indurated and rarely 


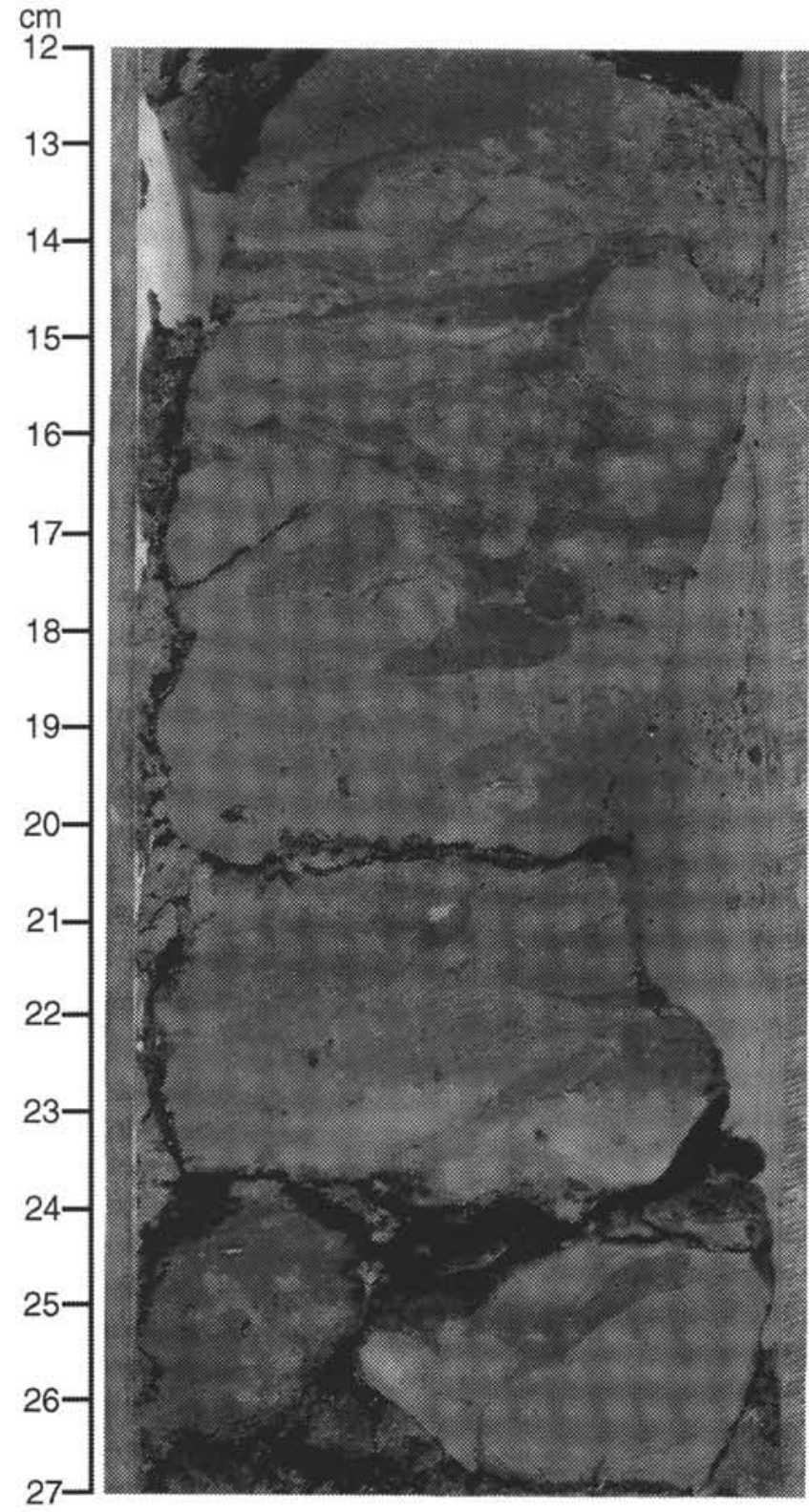

Figure 4. Slump structure in siderite-rich clay (light and medium gray in photograph) and silty clay. Core photograph of Sample 151-909C-94R-3, 12-27 $\mathrm{cm}$.

found. Fe monosulfides are associated with some carbonate beds and burrows.

\section{Site 913}

Below $423.5 \mathrm{mbsf}$, poorly to well-indurated carbonate-rich layers and nodules, $1.5-11 \mathrm{~cm}$ thick, occur in Subunits IIIB and IIIC and Unit IV. These layers and nodules are characteristically dark yellowish brown to olive gray, and exhibit planar laminations, a massive texture, or bioturbation; Zoophycos, Chondrites, and Planolites are recognized locally (Fig. 6). Poorly preserved tests of the marine microfossil, Bolboforma, are abundant in some layers in Subunit IIIC and Unit IV (Fig. 7; D. Spiegler, pers. comm., 1995). Scattered barite crystals, up to $2 \mathrm{~mm}$ long, are associated with the Bolboforma-rich layers in Subunit IIIC (595.-616.0 mbsf). Contacts between carbonate and noncarbonate sediment are gradational or sharp.

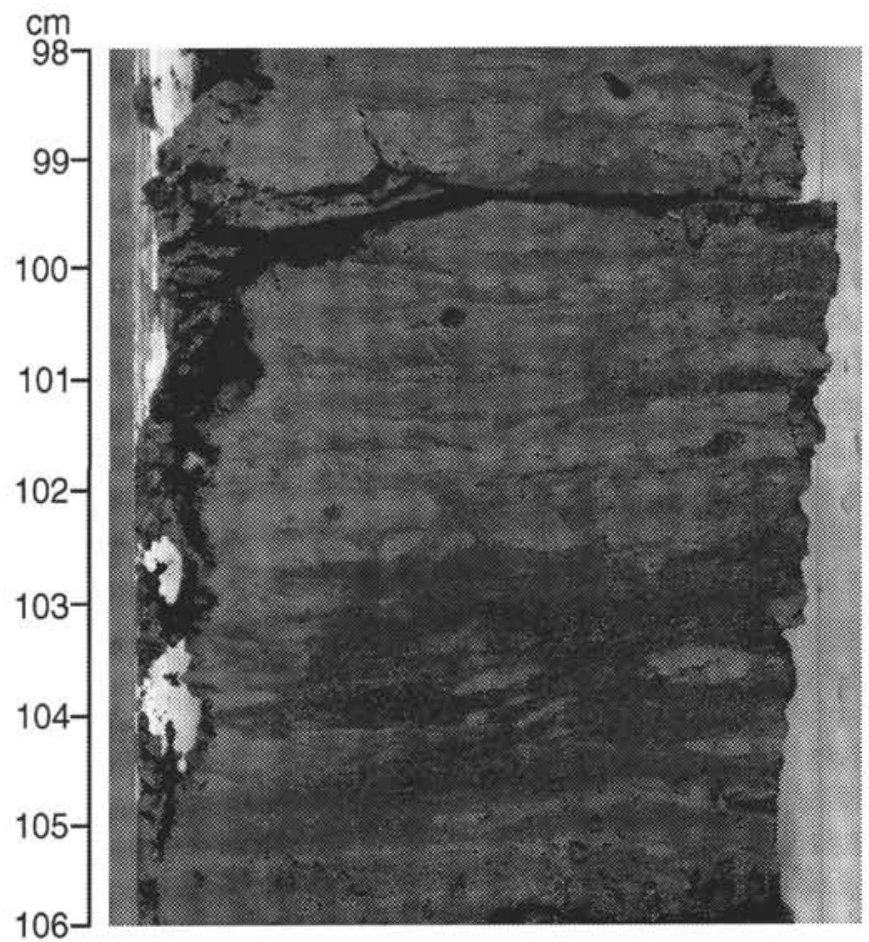

Figure 5. Planolites-like burrows containing siderite (light gray in photograph). Some burrows have Fe sulfide core (black blebs in photo). Core photograph of Sample 151-909C-83R-2, 98-106 cm.

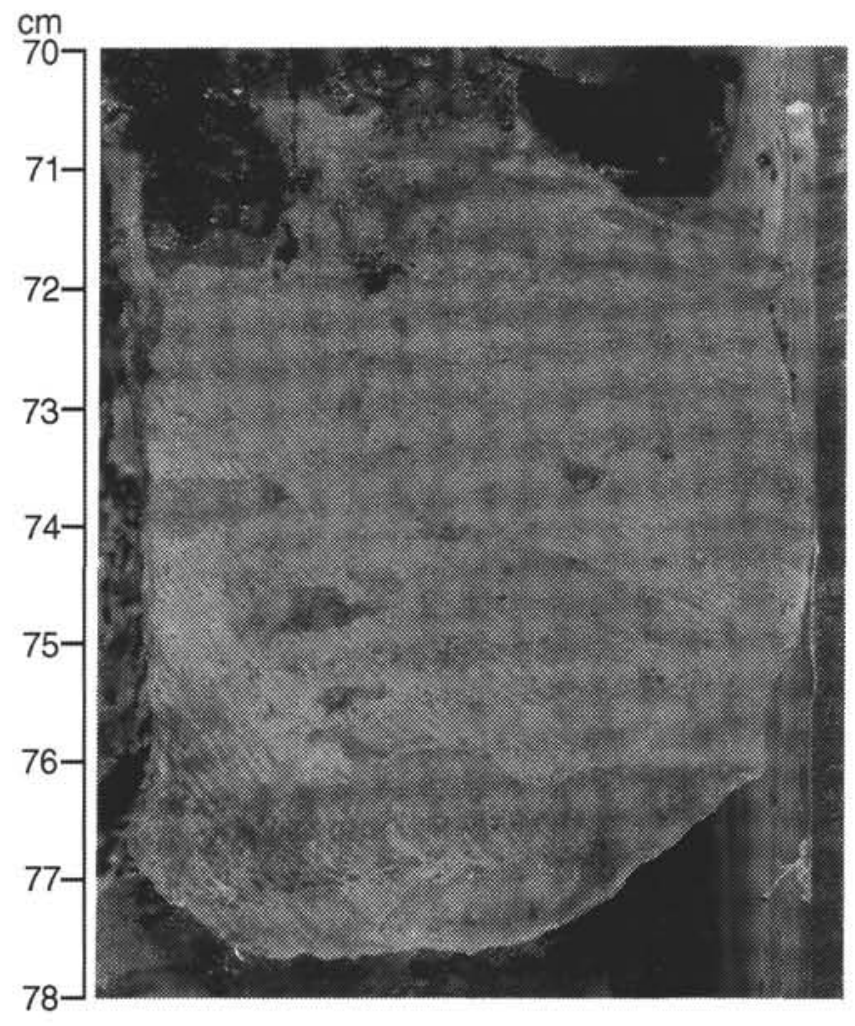

Figure 6. Well-indurated rhodochrosite-rich layer (light gray in photograph), showing pelleted Zoophycus burrows (lower part of photograph). Core photograph of Sample 151-913B-32R-2, 70-78 cm. 


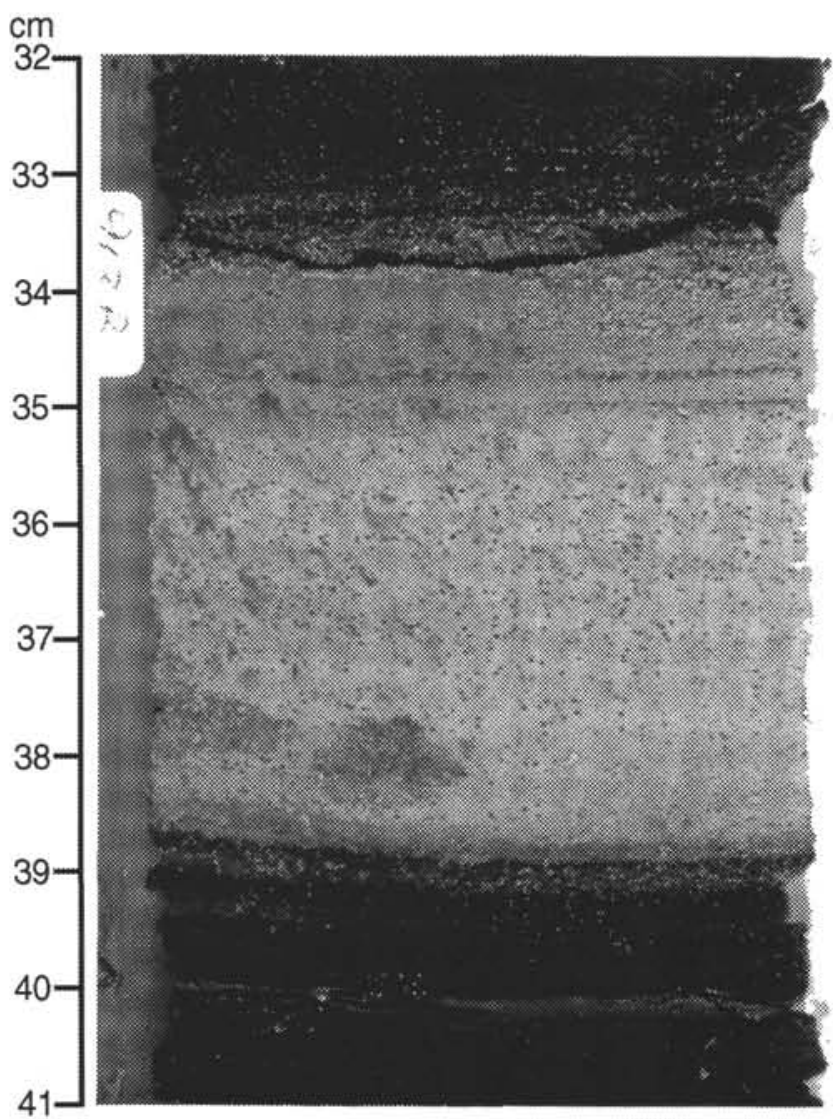

Figure 7. Moderately indurated rhodochrosite-rich layer (light gray in photograph) containing abundant altered Bolboforma (spheroidal specks, $<1 \mathrm{~mm}$ in diameter, in photograph). Core photograph of Sample 151-913B-27R-6, 32$41 \mathrm{~cm}$.

In Unit IV, dm-thick, fining-upward sequences of clayey mud and clay are capped by thin, olive gray carbonate beds (702.7-721.9 mbsf). These beds are bioturbated, and have sharp bottom contacts and gradational top contacts. Rare beds have a lumpy appearance, apparently caused by differential compaction. Slump structures in Unit IV (693.0-721.9 mbsf) also contain cm-size, irregularly shaped patches of carbonate. Below 721 mbsf, two short cores of calcite-cemented sandstone and siltstone were retrieved from 721.9 to 731.6 mbsf and 760.7 to $770.3 \mathrm{mbsf}$, respectively.

\section{Downhole Data}

Suites of wireline logs were recorded for Sites 909 (Hole 909C; 0-1013 mbsf) and 911 (Hole 911 A; 0-476 mbsf). These logs included natural gamma-ray, sonic velocity, and resistivity logs; geochemical logs were also obtained for Site 911 (Hole 911A; 0-445 mbsf). Carbonate sediments and rocks tend to have lower gamma-ray values and higher sonic velocity and resistivity values than adjacent finegrained siliciclastics. Carbonate-rich layers and nodules observed in cores from Sites 909 and 911 produced discernible "spikes" on the gamma-ray, sonic velocity, and resistivity logs, and the geochemical $\log$ (Fe concentrations) for Site 911. However, the presence of numerous other spikes on these logs that appear to be unrelated to carbonates indicates that logging data alone cannot be used to detect carbonate-rich layers and nodules at these sites.

\section{MINERALOGY AND STRATIGRAPHIC DISTRIBUTION OF AUTHIGENIC CARBONATES}

Based on XRD data, authigenic carbonates recovered from Sites 909,911 , and 913 are typically mixtures of rhodochrosite, siderite, dolomite, and calcite. Typical diffraction diagrams are shown in Figure 8 , and the stratigraphic distribution, relative peak intensities, and $d(104)$ values of the carbonates are given in Figures 9-14.

$\mathrm{Mn}$ and $\mathrm{Fe}$ carbonates were detected only in samples from Site 913 and occur in concentrations between 5 and 31 wt\% (Fig. 13). One-third of the samples shows sharp, carbonate reflections, having $d$ (104) values that range from 2.819 to $2.831 \AA$ and appear to decrease slightly with depth (Fig. 14). These values are greater than those of pure siderite $(2.795 \AA)$ and slightly smaller than those of pure rhodochrosite $(2.84 \AA$ ), suggesting an isomorphous mixture of the two end-ember carbonates-manganoan siderite and/or ferroan rhodochrosite (cf. von Rad and Botz, 1987). However, reliable identification of these carbonates requires chemical composition data (refer to the following section) because of possible partial substitution by $\mathrm{Ca}, \mathrm{Mg}$, or other cations. The remaining samples have broad reflections that are composed of multiple peaks. Their $d(104)$ values range from 2.812 to $2.869 \AA$, which are intermediate between pure siderite and stoichiometric dolomite $(2.886 \AA)$. The higher values, between 2.84 and $2.869 \AA$, correspond to those obtained for Ca-rich rhodochrosite in previous studies (e.g., Bohrmann and Thiede, 1989), but reliable identification requires chemical composition data (refer to the following section). There is no obvious stratigraphic pattern of sharp and broad, carbonate reflection peaks.

Siderite is the most common carbonate mineral from Sites 909 and 911 , occurring in most samples in concentrations of 5-60 wt\% (Figs. 9, 11; Shipboard Scientific Party, 1995b, 1995c). The $d(104)$ peaks of siderite are typically sharp and have values ranging from 2.784 to $2.807 \AA$ (Figs. 10, 12).

Calcite and dolomite have been identified at shallow depths at Site 909 (above $167 \mathrm{mbsf}$ ) and sporadically in samples from Sites 911 (40-460 mbsf) and 913 (500-722 mbsf). Calcite contents are as high as $30 \mathrm{wt} \%$, and $d(104)$ spacing is between 3.016 and $3.032 \AA$ at Site 909 and between 2.981 and $3.033 \AA$ at Sites 911 and 913 . These values are slightly less than those for pure calcite $(3.035 \AA)$, probably as a result of minor substitution by cations with smaller ionic radii than that of $\mathrm{Ca}$. Dolomite contents are as high as $5 \mathrm{wt} \%$ and $d(104)$ values range from 2.880 to $2.903 \AA$. Values smaller than that of stoichiometric dolomite $(2.886 \AA)$ may be due to an excess of $\mathrm{Mg}$, whereas the larger values are due to variable substitution of $\mathrm{Ca}$ and/ or $\mathrm{Fe}$ for $\mathrm{Mg}$.

\section{PETROGRAPHY AND GEOCHEMISTRY OF AUTHIGENIC CARBONATES}

\section{Rhodochrosite}

Rhodochrosite in carbonate-rich layers and nodules from Site 913 occurs as microspherules, $20-600 \mu \mathrm{m}$ in diameter, and euhedral and subhedral rhombohedrons, up to $80 \mu \mathrm{m}$ in size (Pl. 1, Figs. 1, 2). The microspherules and rhombohedrons grew displacively, as evidenced by the displacement of the host sediments. In some cases, individual microspherules and rhombohedrons have coalesced to form local aggregates or to cause massive cementation of mud. Relict biogenic particles (diatoms, radiolarians?) and burrows are recognizable locally.

Individual microspherules are spheroidal to subpolygonal in shape and are commonly composed of radial-fibrous and -prismatic crystals (Pl. 1, Fig. 1; Pl. 4, Fig. 5). Microspherules typically show concentric zoning that varies considerably between and within sam- 


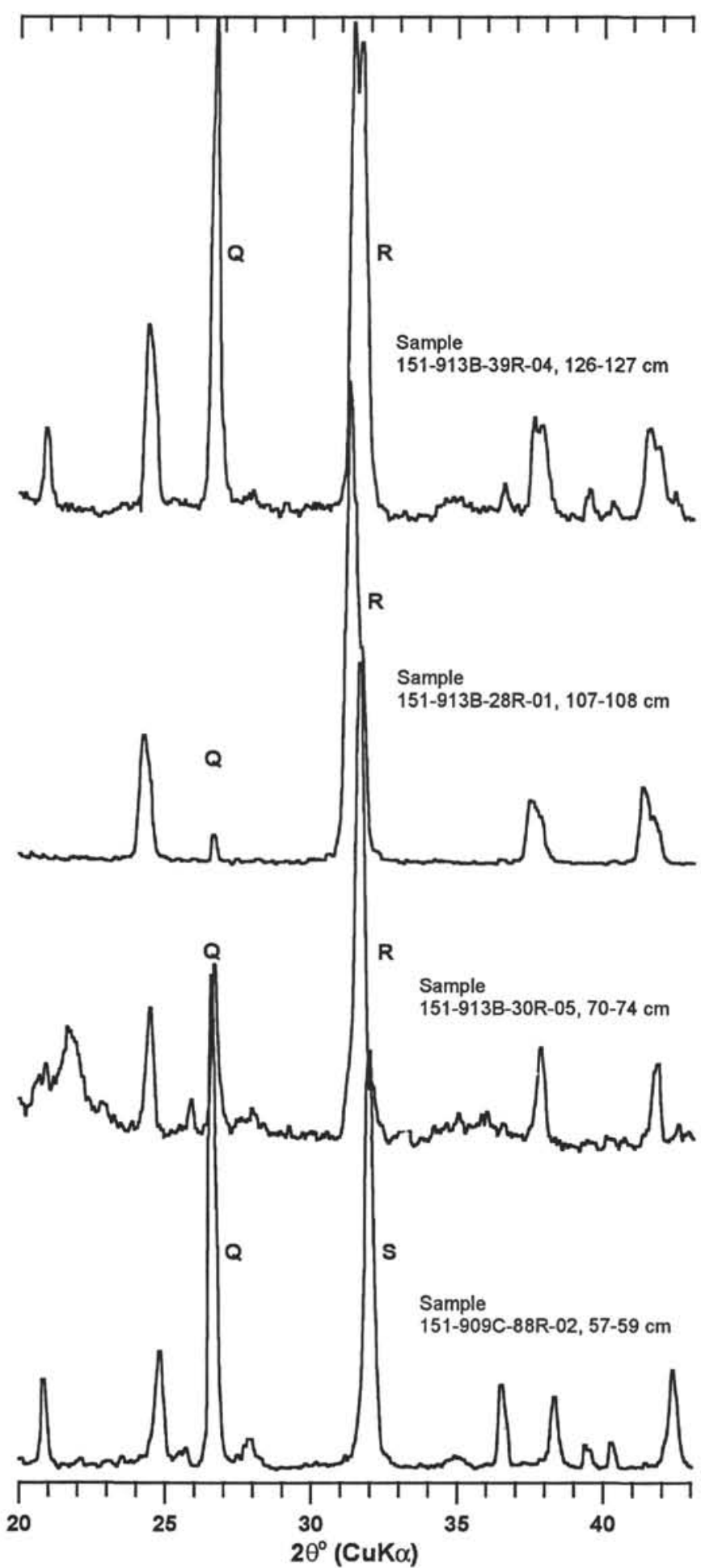

Figure 8. Representative $\mathrm{X}$-ray diffractograms showing the position and shape of the major peaks of rhodochrosite (R), siderite (S), and quartz (Q).

ples. Ideally, a zoned microspherule consists of (1) a dark brown, microcrystalline inner core, $10-50 \mu \mathrm{m}$ in diameter, which may enclose microcrystalline pyrite; (2) an outer core, up to $150 \mu \mathrm{m}$ wide, of light and/or medium brown, radial-fibrous crystals; and (3) a colorless rim, up to $80 \mu \mathrm{m}$ wide, of radial-fibrous and -prismatic crystals. The inner and outer core show dark and moderate green fluorescence, respec- tively, whereas the rim shows moderate green fluorescence with an outermost dark green fringe. Partial dissolution of the core is apparent in some samples.

More uncommon types of microspherules include those that have a thin $\operatorname{rim}(<40 \mu \mathrm{m})$ of rhodochrosite and a core of clay or cryptocrystalline silica (Pl. 1, Figs. 5, 6). Some microspherules in one particular sample have coalesced into collomorphic aggregates that are up to 1 $\mathrm{mm}$ in size and are overgrown by a rim of colorless, radial-prismatic crystals, 50-120 $\mu \mathrm{m}$ thick (Pl. 2, Figs. 1,2). In another sample, microspherules lack concentric zoning and are composed of fan-like arrays of fibrous crystals, which have replaced undistorted diatoms (Pl. 2, Figs. 3, 4).

Large (200-600- $\mu \mathrm{m}$ diameter) microspherules, comprising some of the carbonate-rich layers in the interval between 422.9 and 686.8 mbsf at Site 913, have been identified as altered tests of Bolboforma on the basis of their external morphology (Pl. 2, Figs. 5, 6; D. Spiegler, pers. comm., 1995). Replacement of the low-Mg calcite tests by rhodochrosite has obliterated the primary microstructure, leaving only concentric zoning. The brown core of the microspherules appears to be the replaced Bolboforma and the colorless, radial-fibrous rim appears to be a cement overgrowth.

Rhodochrosite rhombohedrons occur as interparticle cement between microspherules (Pl. 1, Fig. 1) and are disseminated throughout the mud matrix in the middle of carbonate-rich layers and nodules (Pl. 3, Figs. 1-4). They are more abundant toward the margins of layers and nodules and, in some cases, are the main components, as described below. Some samples contain rhombohedrons that have a dark brown core composed of microcrystalline (1-5 $\mu \mathrm{m}$ in size) and framboidal (10-20 $\mu \mathrm{m}$ diameter) pyrite.

Systematic variations in the size and zoning of microspherules and rhombohedrons occur within individual carbonate-rich layers and nodules. In general, large and undistorted microspherules tend to comprise the inner part of the layer or nodule, where they form dense aggregates (Pl. 1, Fig. 1; Pl. 4, Fig. 5). Small rhombohedrons may occur between the microspherules. Toward the outer part of the layer or nodule, the microspherules become more widely spaced and decrease in overall size (Pl. 1, Fig. 2; Pl. 4, Fig. 6). The inner and outer core of the microspherules are smaller, and in some cases nonexistent, and the rim is composed predominantly of rhombohedral crystals. These outer microspherules are commonly distorted, probably because of mechanical compaction, and appear to be recrystallized radial-fibrous/prismatic microspherules. In contrast, some carbonate-rich layers contain alternating laminae of different types of microspherules: porous laminae of microspherules that have a "typical" core and rim, as described previously, alternating with dense laminae of small$\mathrm{er}$, irregularly shaped microspherules that have only a microcrystalline and/or radial-fibrous "core" (PI. 3, Fig. 5). In certain bioturbated layers, dense concentrations of small ( $20-30 \mu \mathrm{m}$ in size) microspherules completely or partially replace burrow structures, helping to preserve some relict structure, and are encased in larger (up to $100 \mu \mathrm{m}$ in size) microspherules and rhombohedrons (Pl. 3, Fig. 6).

Euhedral barite crystals, up to $2 \mathrm{~mm}$ long, occur as accessory minerals between microspherules and rhombohedrons in the mud matrix and, in some cases, engulf and partially replace them (Pl. 2, Fig. 5). Barite also partially or completely fills some interparticle voids (PI. 2, Figs. 1, 2), molds in microspherule cores (Pl. 1, Fig. 6), and fractures that cut across microspherules and matrix.

Rhodochrosite microspherules from Site 913 are ferroan, containing less than $46 \mathrm{~mol} \% \mathrm{FeCO}_{3}$ (Table 1). $\mathrm{Ca}$ and $\mathrm{Mg}$ contents are relatively low, generally below 11 and $5 \mathrm{~mol} \%$, respectively. BSE imaging revealed a chemical zonation in concentric microspherules that is highly variable between samples and, to a certain extent, even within the same sample. The cores of microspherules in some samples are more enriched in $\mathrm{Fe}$ and $\mathrm{Mn}$, but are depleted in $\mathrm{Ca}$, relative to the rims (Pl. 2, Fig. 6). In other samples, the cores are more enriched in $\mathrm{Mn}, \mathrm{Ca}$, and/or $\mathrm{Mg}$, but contain much less $\mathrm{Fe}$, than the rims 


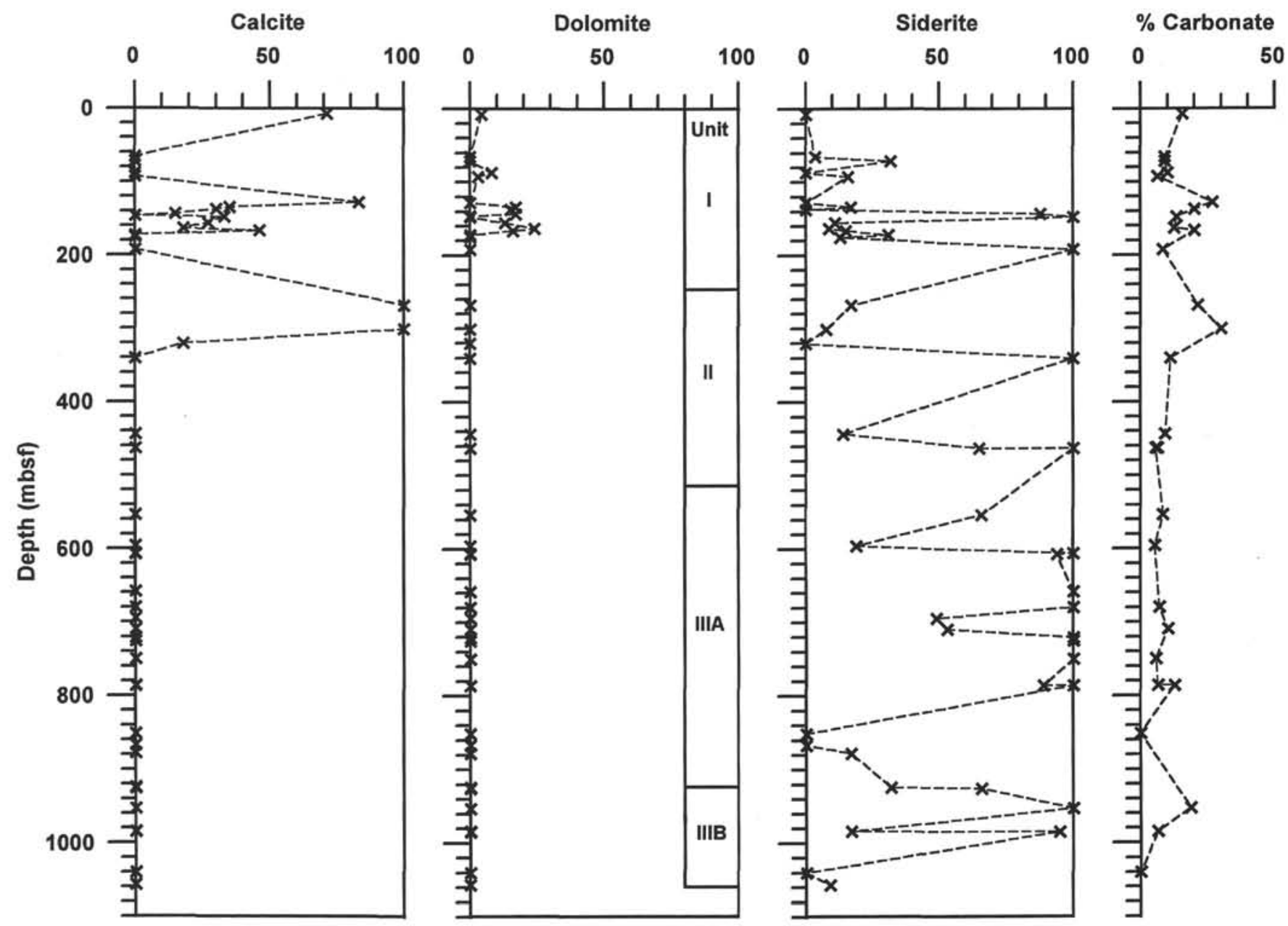

Figure 9. Variations in relative peak intensity (\%) of authigenic carbonates and total carbonate content vs. depth at Site 909.

(Pl. 1, Fig. 4); some samples even have rims that are partially manganoan siderite (see the following section). Some microspherules show little chemical variation between the core and rim (Pl. 1, Fig. 3).

Discrete, rhodochrosite rhombohedrons show variations in chemical composition on a sample scale, having $\mathrm{Fe}$ contents that range from 24 to $48 \mathrm{~mol} \%$ and $\mathrm{Ca}$ and $\mathrm{Mg}$ contents of less than $8 \mathrm{~mol} \%$ and $5 \mathrm{~mol} \%$, respectively (Table 1). Zoned crystals tend to have a core with higher $\mathrm{Mn}$ and $\mathrm{Ca}$ content, but lower $\mathrm{Fe}$ content, than the rim.

The $\delta^{13} \mathrm{C}$ values of rhodochrosite vary from $-18.5 \%$ to $-13.8 \%$ o (Fig. 15; Table 1) and show decreasing values with depth (Fig. 16). The $\delta^{18} \mathrm{O}$ values vary widely between $-11.8 \%$ and $+1.5 \%$ (Fig. 15; Table 1) and show a less pronounced negative trend with depth (Fig. 17). Preliminary analysis of the center and margin of individual rhodochrosite nodules showed no significant differences in their $\delta^{13} \mathrm{C}$ and $\delta^{18} \mathrm{O}$ values (Sample 151-913B-32R-2, 57-61 cm; Table 1).

\section{Siderite}

Carbonate-rich layers and nodules from Sites 909 and 911 typically contain varying amounts of very fine to fine-crystalline ( $1-25 \mu \mathrm{m})$, equant crystals of siderite that occur as interparticle cement, in irregular patches or as disseminated crystals in muds (Pl. 4, Figs. 1,2). Microcrystalline siderite also comprises rounded intraclasts, up to 250 $\mu \mathrm{m}$ in diameter (Pl. 4, Fig. 2). The siderites are slightly to considerably enriched in $\mathrm{Ca}$ and/or $\mathrm{Mg}$ (up to $13 \mathrm{~mol} \%$ and $15 \mathrm{~mol} \%$, respectively) and have a lower Mn content ( $<7.2 \mathrm{~mol} \%$; Table 1).

Several samples recovered from Site 913 contain microspherules that have rims, up to $50 \mu \mathrm{m}$ wide, of predominantly radial-prismatic manganoan siderite (Pl. 4, Fig. 3). BSE imaging of these microspherules, as well as some of the ferroan rhodochrosite ones (Pl. 4, Figs. 4-6), revealed irregular, radial strips of siderite that occur throughout the rim and as an outermost rind. This siderite is more enriched in $\mathrm{Ca}$ and $\mathrm{Mg}$ than the surrounding siderite or rhodochrosite.

The $\delta^{13} \mathrm{C}$ and $\delta^{18} \mathrm{O}$ values of the siderite vary widely from $-22.3 \%$ to $+7.9 \%$ and between $-11.4 \%$ and $+2.5 \%$, respectively (Figs. 15, 18: Table 1). Siderites from Site 913 are characterized by lower $\delta^{13} \mathrm{C}$ and $\delta^{18} \mathrm{O}$ values than those from Site 909 . The $\delta^{13} \mathrm{C}$ and $\delta^{18} \mathrm{O}$ values of siderite show a negative trend with depth at Site 913 (Figs. 16, 17), similar to rhodochrosite, but display peculiar fluctuations at Site 909 (Figs. 19, 20). It is also noteworthy that both $\delta^{13} \mathrm{C}$ and $\delta^{18} \mathrm{O}$ trends are generally covariant, except at shallow depths where they show opposite trends.

\section{Calcite and Dolomite}

Authigenic calcite is relatively rare in samples from Sites 909 , 911, and 913. It occurs as an interparticle, and locally displacive, cement with a micritic or radial-fibrous habit and as a fracture-filling, radial-fibrous or blocky cement containing host-sediment inclusions aligned subparallel to the fracture walls. Coarse-crystalline blocky calcite, together microcrystalline siderite, also fills some burrows.

The $\mathrm{Fe}, \mathrm{Mn}$, and $\mathrm{Mg}$ contents of these calcites are typically below $5 \mathrm{~mol} \%$ (Table 1 ). The $\delta^{13} \mathrm{C}$ values vary between $-22.9 \%$ and $-7.6 \%$, and the $\delta^{18} \mathrm{O}$ values vary between $-8.9 \%$ and $+4.1 \%$ (Table 1 ). The low $\delta^{18} \mathrm{O}$ values are typical for calcite from Site 913 (Fig. 17). 


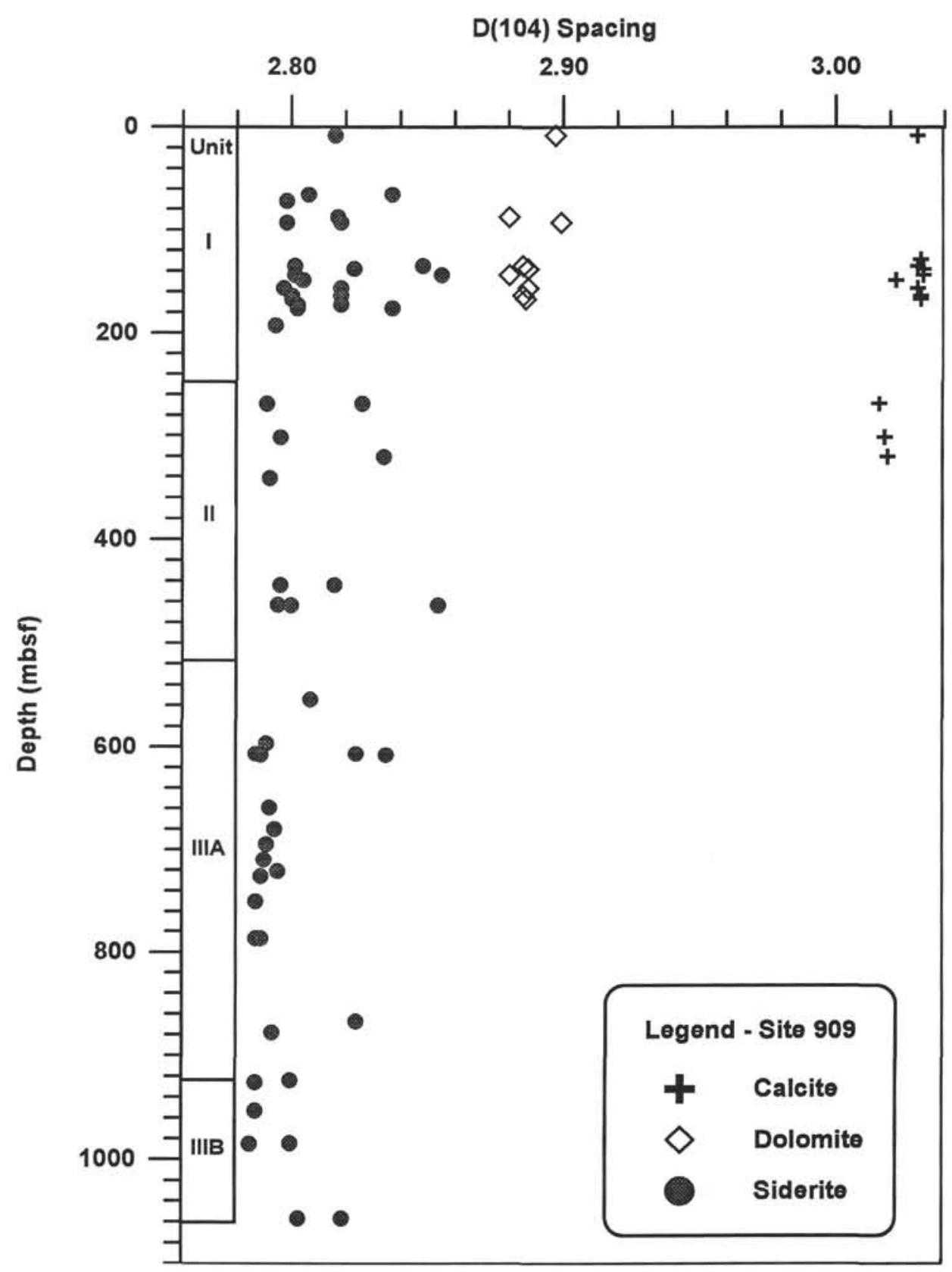

Figure 10. Variations in $d(104)$ spacing of authigenic carbonates vs. depth at Site 909.

Although dolomite has been identified by XRD analysis in several samples from Sites 909,911, and 913, only one sample analyzed by BSE imaging from Site 909 contained authigenic dolomite (Sample 151-909C-40R-2, 56-60 cm; Table 1). This dolomite $\left(\mathrm{Ca}_{55.0} \mathrm{Mg}_{39.1} \mathrm{Fe}_{4.5} \mathrm{Mn}_{0.2}\right)$ occurs as disseminated crystals, $<15 \mu \mathrm{m}$ in size, throughout the host sediment.

\section{DISCUSSION}

The presence of only calcian and/or magnesian siderite at Sites 909 and 911 and ferroan rhodochrosite and manganoan siderite at Site 913 suggests important geochemical variations between these three sites at the time of carbonate precipitation. The following discussion provides some preliminary interpretations of the petrograph- ic, mineralogical, and geochemical data necessary to decipher the processes, environmental conditions, and pore water evolution that gave rise to these authigenic carbonates.

\section{Timing of Carbonate Precipitation}

Determination of the relative timing of carbonate authigenesis is a key component in the interpretation of the elemental and isotopic data in that it delimits possible formation temperatures, water compositions and organic processes. Authigenic $\mathrm{Mn}$ and $\mathrm{Fe}$ carbonates in sediments at Sites 909,911 , and 913 presently occur at depths between approximately 70 and $1050 \mathrm{mbsf}$. However, petrographic observations suggest that carbonate precipitation at these sites occurred largely at shallow burial-depths during early diagenesis (i.e., before significant mechanical compaction). The evidence includes (1) 


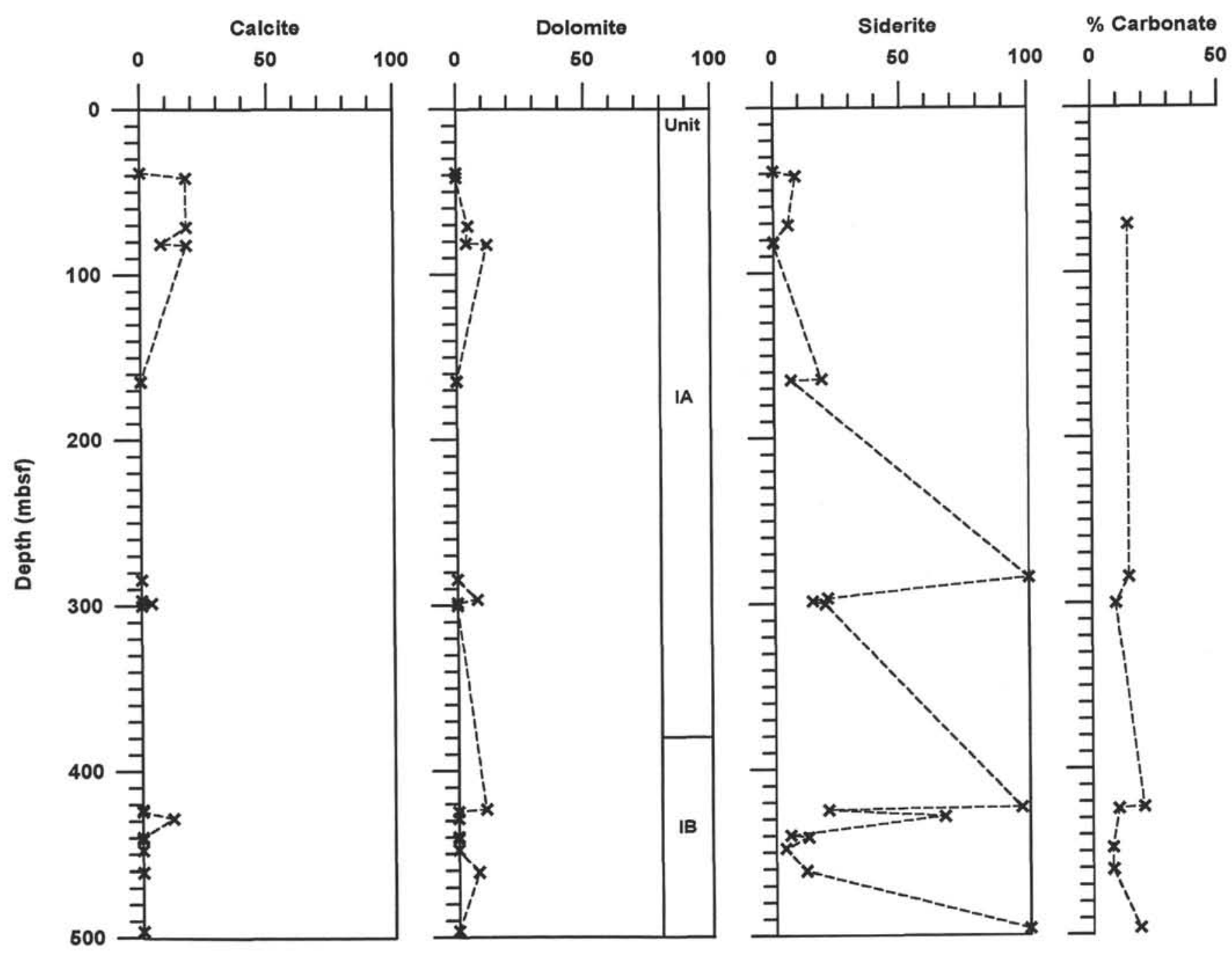

Figure 11. Variations in relative peak intensity (\%) of authigenic carbonates and total carbonate content vs. depth at Site 911.

rounded intraclasts composed of microcrystalline siderite at Site 909, which indicates synsedimentary lithification and subsequent reworking; (2) abundance of siderite cement at Sites 909 and 911, which suggests high pre-cement porosity; (3) displacive growth of rhodochrosite microspherules and rhombohedrons at Site 913; (4) distorted rhodochrosite microspherules at the margins of carbonate layers and nodules at Site 913, which suggests that rhodochrosite precipitation was earlier than or partly concomitant with mechanical compaction; and (5) preservation of relatively undeformed burrow structures within many carbonate-rich layers and nodules.

\section{$\delta^{13} \mathrm{C}$ Signatures, TOC Content, and Diagenetic Zones}

Precipitation of $\mathrm{Mn}$ and $\mathrm{Fe}$ carbonates in marine sediments commonly occurs at shallow burial depths in the $\mathrm{Mn}$ - and $\mathrm{Fe}$-reduction zones, respectively (Berner, 1981). Mn and Fe reduction can become important in suboxic conditions at depths as shallow as centimeters or decimeters below the seafloor (Froelich et al., 1979). Authigenic carbonates formed under such conditions have $\delta^{13} \mathrm{C}$ values that reflect the following factors: (1) oxidation of marine organic matter $\left(\delta^{13} \mathrm{C} \approx-25 \% \circ\right) ;(2)$ the $\delta^{13} \mathrm{C}$ composition of dissolved carbon in marine waters (e.g., pore water $\delta^{13} \mathrm{C} \approx-3.1$ to $-2.0 \%$; McCorkle and Emerson, 1988); and (3) carbon derived from the dissolution of marine biogenic carbonates $\left(\delta^{13} \mathrm{C} \approx 0 \%\right.$ ). The resultant $\delta^{13} \mathrm{C}_{\text {carbonate }}$ is usually equal to or more positive than $-6 \%$ (McArthur et al., 1986).
Most of the siderites from Site 909 have $\delta^{13} \mathrm{C}$ values that are close to $-6 \%$, which suggests an origin in the Fe-reduction, suboxic zone. However, a few samples have considerably lower $\delta^{13} \mathrm{C}$ values (e.g., $-21.8 \%,-18.5 \%$ ) , indicating essential derivation of dissolved carbon from the oxidation of marine organic matter in the bacterial sulfate-reduction zone (cf. Irwin et al., 1977). This finding is supported by the close association between siderite and authigenic pyrite in these samples in which pyrite is engulfed by, and hence predates, the siderite. Enrichment of dissolved carbon in ${ }^{12} \mathrm{C}$ may also be related to early stages of methanogenesis, subsequent to depletion of pore waters in dissolved sulfate (cf. Whiticar and Faber, 1986). Only one siderite sample from Site 909 , enriched in ${ }^{13} \mathrm{C}\left(\delta^{13} \mathrm{C} \approx+7.9 \%\right.$ ), showed clear evidence for origin in the methanogenesis zone (cf. Irwin et al., 1977).

Moderate to high organic matter content (TOC values up to 2.6 $\mathrm{wt} \%)$ and methane concentration (10,000-75,000 ppm) at Site 909 (Shipboard Scientific Party, 1995b) further corroborate the importance of anaerobic microbial processes. TOC values have been used to divide the sedimentary succession as follows:

0-140 mbsf (upper Pliocene to Quaternary): $0.2-1.4$ wt\% TOC; 140-645 mbsf (upper Miocene to upper Pliocene): 0.8-1.7 wt \% TOC;

645-992 mbsf (upper Miocene): 0.3-1.2 wt\% TOC;

992-1062 mbsf (lower to middle Miocene): 1.4 to $2.6 \mathrm{wt} \%$ TOC. 


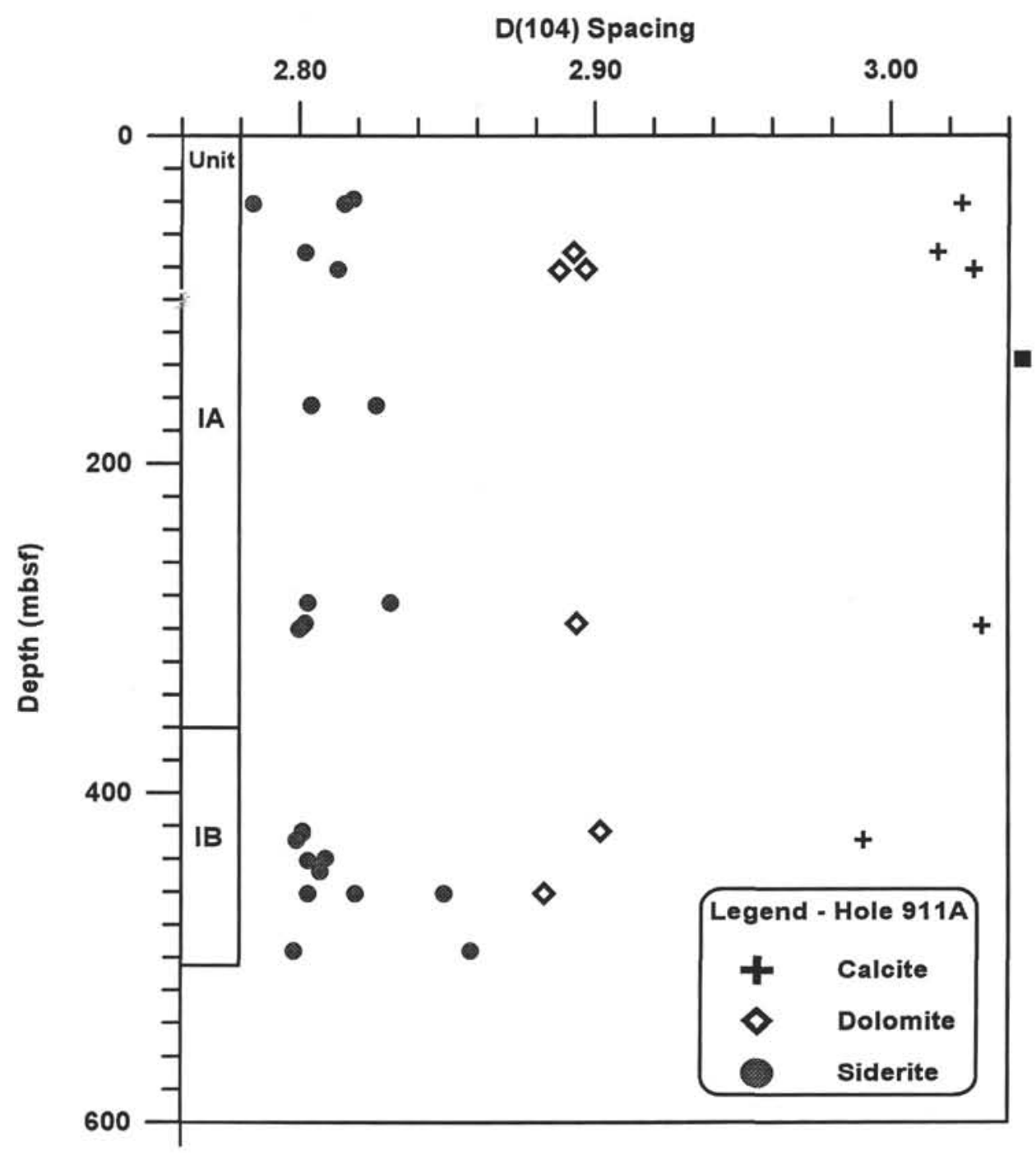

Figure 12. Variations in $d(104)$ spacing of authigenic carbonates vs. depth at Site 911.

Low $\mathrm{C} / \mathrm{N}$ ratios $(<10)$ suggest that abundant marine organic matter is preserved in the sediments (Shipboard Scientific Party, 1995b). Siderite is present throughout much of the sedimentary succession at Site 909, and its occurrence does not appear to coincide with intervals of elevated TOC content. This is surprising, as high TOC would imply increased alkalinity of the pore waters, which would favor carbonate precipitation. High headspace methane/ethane $\left(\mathrm{C}_{1} / \mathrm{C}_{2}\right)$ ratios $(900-12,000)$ at depths above 400 mbsf at Site 909 reflect in situ microbial methane production from the abundant marine organic carbon (Shipboard Scientific Party, 1995b); in Hole 909A, methanogenesis is postulated to have begun above 25 mbsf. The high methane concentrations may also be related to the presence of gas hydrates (Claypool and Kaplan, 1974), although there is no evidence for their presence at Site 909.

In contrast to Site 909, all authigenic carbonates from Site 913 (rhodochrosite, siderite, and calcite) are strongly enriched in ${ }^{12} \mathrm{C}$ $\left(\delta^{13} \mathrm{C}=-22.9\right.$ to $-13.8 \%$ ). Low $\delta^{13} \mathrm{C}$ values, along with the pyrite commonly found at the core of these carbonates, suggest derivation of dissolved carbon from the oxidation of organic matter in the bacterial sulfate-reduction zone, and probably from the early stages of methanogenesis. This is seen in the decreasing $\delta^{13} \mathrm{C}$ values with depth. However, the organic matter content and methane concentrations are very low in the sedimentary succession at Site 913 (Shipboard Scientific Party, 1995d). TOC values, which generally vary between 0.1 and $1 \mathrm{wt} \%$, show some peak values as high as 2 to $5.2 \mathrm{wt} \%$ in the lower part of the succession (below $500 \mathrm{mbsf}$ ). High $\mathrm{C} / \mathrm{N}$ ratios, up to 37 , in this lower part suggest that the TOC peaks are due to increased terrigenous clastic input (Shipboard Scientific Party, 1995d). Many of the authigenic carbonates analyzed from Site 913 (530.97-717.94 mbsf) occur within the peak TOC intervals; however, poor core recovery in the upper $423.5 \mathrm{~m}$ of the succession precludes definitive comparison of carbonate distribution and organic content. Headspace methane concentrations are commonly $<10 \mathrm{ppm}$, more than four orders of magnitude lower than those recorded at Site 909.

Low organic matter content and headspace methane concentrations at Site 913 suggest that dissolved carbon may also have been partly derived from thermogenic methane, diffusing upward with hydrothermal fluids in the area. Diffusion of methane and hydrothermal fluids supplied carbon and calcium for carbonate precipitation that would be enhanced by high alkalinity resulting from sulfate reduction (e.g., Al-Aasm and Blaise, 1991; Baker et al., 1994). Thermogenic 


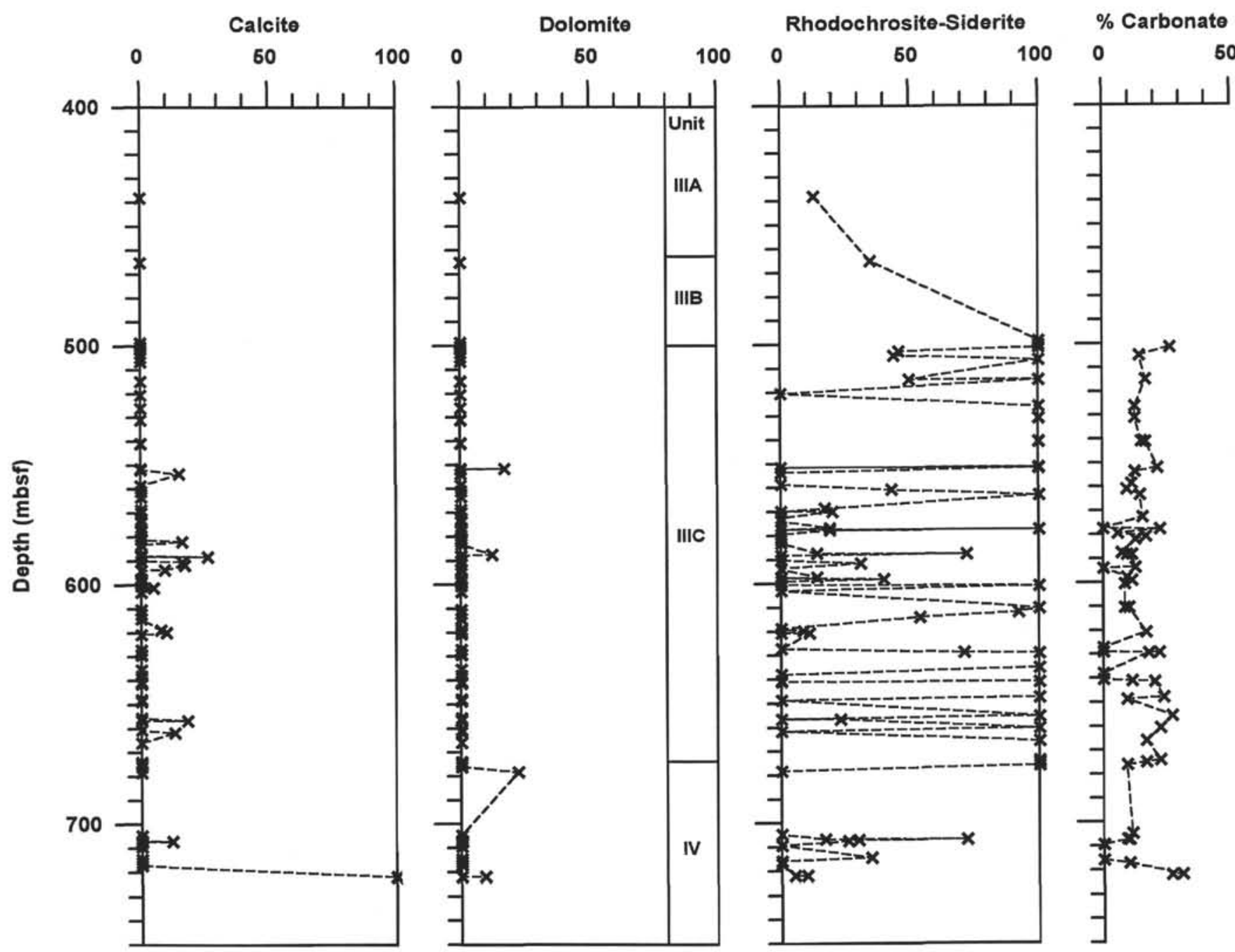

Figure 13. Variations in relative peak intensity (\%) of authigenic carbonates and total carbonate content vs. depth at Site 913.

methane requires temperatures in excess of $75^{\circ} \mathrm{C}$ and is less fractionated than biogenic methane $\left(\delta^{13} \mathrm{C}=-50\right.$ to $-30 \%$ or the former and -90 to $-75 \%$ for the latter; Ritger et al., 1987).

\section{Constraints from $\delta^{18} \mathrm{O}$ Signatures}

The variations in $\delta^{18} \mathrm{O}$ values between authigenic carbonates from Sites 909, 911, and 913 may be related to several factors: (1) increase in pore water temperature; (2) sediment-water interaction, generating ${ }^{18} \mathrm{O}$-depleted pore waters (Aagaard et al., 1989; Morad and De Ros, 1994); (3) incursion of meteoric waters (e.g., Emery et al., 1988; MacKay et al., 1995); and (4) ${ }^{18} \mathrm{O}$-depleted pore waters resulting from organic matter degradation under reducing conditions (e.g., Sass et al., 1991). The latter two factors can be largely discounted for these sites. Evidence for exposure to meteoric water is lacking, and the TOC content of the sediment is too small and the $\delta^{18} \mathrm{O}$ values of the carbonates are too low to apply the organic degradation model, which is based on very organic-rich sediments ( $>50 \mathrm{wt} \%$ TOC; Sass et al., 1991), to the present investigation.

Precipitation of Mn carbonates is strongly dependent on the amount and solubility of Mn oxides/oxyhydroxides (herein referred to as Mn minerals), the amount and reactivity of organic matter, and the redox potential of the bottom waters (Froelich et al., 1979). At
Site 913 , the abundance of rhodochrosite suggests conditions favoring the formation of $\mathrm{Mn}$ carbonates, specifically a source of $\mathrm{Mn}$ in the form of reactive detrital $\mathrm{Mn}$ minerals and relatively oxygenated bottom conditions. With burial, the Mn minerals would have been dissolved in the Mn-reduction zone to later precipitate Mn carbonates. The $\mathrm{Fe}$ content of the rhodochrosite suggests overlap between the Mn-reduction and Fe-reduction zones. In contrast, the absence of rhodochrosite in organic-rich sediments at Site 909 may be attributed either to the lack of reactive detrital Mn minerals and/or to anoxic bottom conditions.

The occurrence of Mn carbonates at Site 913 may also be related to the circulation of $\mathrm{Mn}$-charged, hydrothermal fluids, possibly related to volcanic activity associated with seafloor spreading in the vicinity of the East Greenland Margin during the Paleogene (cf. Fournier, 1985; Gianelli and Teklemarian, 1993). This hypothesis is supported by several lines of evidence. First, coarse-crystalline barite, which fills fractures and voids, occurs in association with Mn carbonates; it is absent at the other sites. Numerous other studies have noted the common occurrence of barite in hydrothermal veins and nodules (AlAasm and Blaise, 1991; Deer et al., 1992). Second, some of the $\delta^{18} \mathrm{O}$ values for $\mathrm{Mn}$ carbonates are very low $\left(-11.8 \%\right.$ ). These $\delta^{18} \mathrm{O}$ values are assumed not to be due to fractionation differences caused by incorporation of large amounts of $\mathrm{Mn}$ in the siderite and $\mathrm{Fe}$ in the 


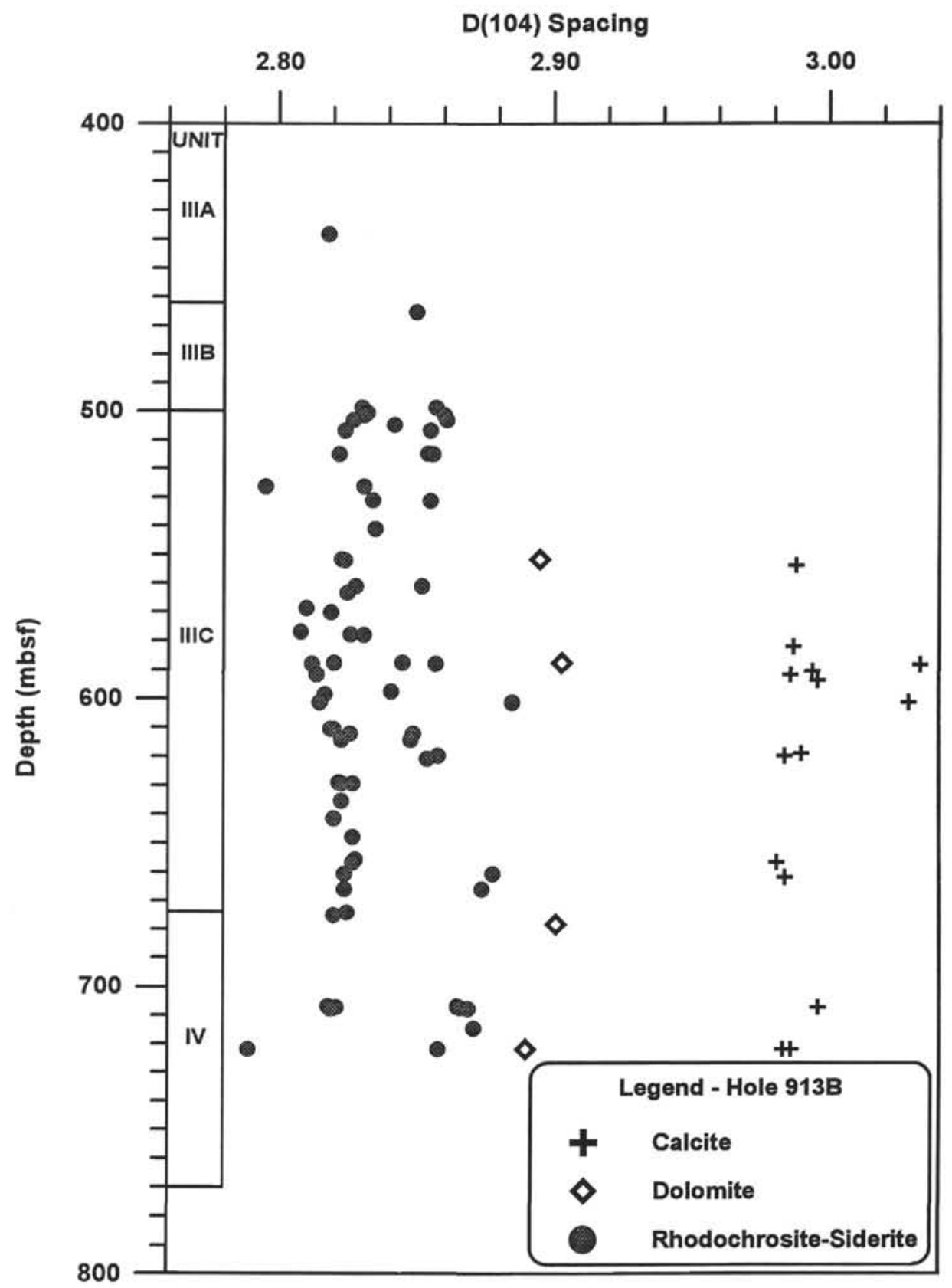

Figure 14. Variations in $d(104)$ spacing of authigenic carbonates vs. depth at Site 913.

rhodochrosite. This assumption is further corroborated by the low $\delta^{18} \mathrm{O}$ values for calcite from Site $913\left(\delta^{18} \mathrm{O} \approx-8.9\right.$ to $\left.-7.9 \%\right)$ compared to calcites from Sites 909 and $911\left(\delta^{18} \mathrm{O} \approx+0.4 \%\right.$ and $+4.1 \%$, respectively).

Fractionation of $\delta^{18} \mathrm{O}_{\text {rhodochrosite-water }}$ is not well established (Coleman et al., 1982). However, rhodochrosite is usually enriched in $\delta^{18} \mathrm{O}$ (up to $10 \%$ ) relative to calcite at $25^{\circ} \mathrm{C}$ because of isotopic disequilibrium with pore waters (cf. Vrolijk and Sheppard, 1991). In contrast, fractionation of $\delta^{18} \mathrm{O}_{\text {siderite-water }}$ and $\delta^{18} \mathrm{O}_{\text {calcite-water }}$ is better known (cf. Friedman and O'Neil, 1977; Carothers et al., 1988), permitting estimation of pore-water isotopic chemistry and temperature. Using the average $\delta^{18} \mathrm{O}$ values for siderite and calcite $(-10.5 \%$ and $-8.1 \%$, respectively) at Site 913 , the calculated $\delta^{18} \mathrm{O}$ values of pore water are $-18.4 \%$ SMOW and $-11.8 \%$ o SMOW, respectively, assuming for- mation at $0^{\circ} \mathrm{C}$ bottom temperature. At higher pore-water temperatures (ca. $150^{\circ} \mathrm{C}$ ), the estimated $\delta^{18} \mathrm{O}$ value of pore water using both siderite and calcite values is approximately $+7 \%$ SMOW. This estimate is more reasonable than the previous ones and it is comparable to the values of hydrothermal fluids from magmatic sources $(+7$ to $+10 \%$ SMOW; Hattori and Sakai, 1980; Zheng and Hoefs, 1993).

The range of $\delta^{18} \mathrm{O}$ values for siderite from Sites 909 and $911(-10.3$ to $+5.1 \%$ o appears to be related to both the temperature of the pore waters and sediment-water interaction. The most enriched $\delta^{18} \mathrm{O}$ values of siderite should reflect precipitation at shallow burial temperatures of $8^{\circ} \mathrm{C}$, assuming pore water with an isotopic composition of $\sim 0 \%$ SMOW (using the fractionation equation of Carothers et al., 1988). However, given the present burial depth and geothermal gradient $\left(88^{\circ} \mathrm{C} / \mathrm{km}\right.$ for Site 909$)$, increasing burial temperatures alone cannot 
Table 1. Isotopic and elemental composition of authigenic carbonates in samples from Sites 909, 911, and 913.

\begin{tabular}{|c|c|c|c|c|c|c|c|c|}
\hline $\begin{array}{l}\text { Core, section, } \\
\text { interval }(\mathrm{cm})\end{array}$ & $\begin{array}{l}\text { Depth } \\
\text { (mbsf) }\end{array}$ & Mineralogy & $\begin{array}{c}\delta^{18} \mathrm{O} \\
(\mathrm{PDB}) \\
(\mathrm{ppt})\end{array}$ & $\begin{array}{c}\delta^{13} \mathrm{C} \\
(\mathrm{PDB}) \\
(\mathrm{ppt})\end{array}$ & $\begin{array}{l}\mathrm{FeCO}_{3} \\
(\mathrm{~mol} \%)\end{array}$ & $\begin{array}{l}\mathrm{MnCO}_{3} \\
(\mathrm{~mol} \%)\end{array}$ & $\begin{array}{l}\mathrm{CaCO}_{3} \\
(\mathrm{~mol} \%)\end{array}$ & $\begin{array}{l}\mathrm{MgCO}_{3} \\
(\mathrm{~mol} \%)\end{array}$ \\
\hline \multicolumn{9}{|l|}{$151-909 \mathrm{C}$} \\
\hline 20R-CC, 13-15 & 268.23 & Calcite & +4.07 & -22.82 & & & & \\
\hline 20R-CC, $13-15$ & 268.23 & Siderite & +2.47 & -21.82 & & & & \\
\hline $40 \mathrm{R}-2,56-60$ & 462.66 & Dolomite & & & $4.6-53.3$ & $0.2-1.1$ & $55.7-23.0$ & $39.5-21.0$ \\
\hline $55 \mathrm{R}-1,107-111$ & 606.17 & Siderite & -2.29 & -6.18 & 75.1 & 3.6 & 12.2 & 9.1 \\
\hline $60 R-4,61-64$ & 658.51 & Siderite & -6.24 & -6.03 & & & & \\
\hline $62 R-5,98-101$ & 679.68 & Siderite & -0.91 & -4.08 & 84.9 & 1.3 & 5.4 & 8.4 \\
\hline $67 \mathrm{R}-1,1-3$ & 720.81 & Siderite & +2.48 & +7.86 & 75.0 & 0.5 & 8.9 & 15.6 \\
\hline 68R-CC, Paleo & $\sim 740$ & Siderite & -0.45 & -5.65 & & & & \\
\hline $70 \mathrm{R}-1,28-30$ & 749.88 & Siderite & -5.48 & -18.5 & $89.1-69.9$ & $30.8-61.8$ & $2.7-6.2$ & $3.6-4.0$ \\
\hline $73 R-6,13-17$ & 786.33 & Siderite & -2.03 & -7.38 & 72.1 & 3.0 & 12.1 & 12.8 \\
\hline $82 \mathrm{R}-1,139-140$ & 866.89 & Siderite & & & 78.1 & 1.0 & 10.9 & 10.0 \\
\hline $88 R-2,57-59$ & 925.47 & Siderite & -4.84 & -8.35 & $78.4-84.7$ & $0.5-0.3$ & $11.0-4.0$ & $10.1-11.0$ \\
\hline $91 \mathrm{R}-1,51-54$ & 952.91 & Siderite & -4.64 & -6.62 & & & & \\
\hline $94 \mathrm{R}-3,20-24$ & 984.50 & Siderite & -3.11 & -5.85 & & & & \\
\hline \multicolumn{9}{|l|}{ 151-911A- } \\
\hline $31 X-1,1-3$ & 284.31 & Siderite & +5.05 & -2.55 & 78.7 & 1.2 & 9.9 & 10.2 \\
\hline $31 X-1,1-3$ & 284.31 & Calcite & +0.42 & -7.62 & 0 & 0 & 99.6 & 0.4 \\
\hline $52 X-C C, 5-8$ & 496.12 & Siderite & & & 77.3 & 1.5 & 9.6 & 11.6 \\
\hline \multicolumn{9}{|l|}{ 151-913B- } \\
\hline 28R-1, 107-108 & 501.37 & Rhodochrosite & +1.55 & -13.76 & $0.1-46.5$ & $84.7-44.7$ & $11.8-5.4$ & $1.4-3.4$ \\
\hline $30 \mathrm{R}-1,102-104$ & 520.52 & Rhodochrosite & -3.99 & -17.84 & 39.0 & 50.4 & 8.2 & 2.4 \\
\hline $30 \mathrm{R}-5,70-74$ & 526.2 & Rhodochrosite & -0.67 & -15.16 & $13.8-25.2$ & $72.2-70.6$ & $10.7-2.5$ & $3.3-1.7$ \\
\hline $31 \mathrm{R}-2,27-31$ & 530.97 & Rhodochrosite & -5.64 & -17.51 & 12.4 & 79.5 & 5.9 & 2.2 \\
\hline $32 \mathrm{R}-2,57-61$ & 540.87 & Rhodochrosite (core) & -8.80 & -17.95 & $18.1-45.97$ & $3.6-5$ & $0.44 .9-1.2$ & $3.4-2.5$ \\
\hline $32 \mathrm{R}-2,57-61$ & 540.87 & Rhodochrosite (rim) & -7.31 & -16.96 & & & & \\
\hline $32 \mathrm{R}-2,74-78$ & 541.04 & Rhodochrosite & -5.96 & -17.61 & 15.97 & 3.8 & 6.6 & 3.7 \\
\hline $36 \mathrm{R}-1,37-39$ & 577.77 & Rhodochrosite & -8.28 & -18.31 & $24.8-48.3$ & $62.4-46.3$ & $7.9-1.2$ & $4.9-4.2$ \\
\hline $36 \mathrm{R}-1,47-49$ & 577.87 & Rhodochrosite & & & 9.2 & 81.5 & 5.9 & 3.4 \\
\hline $37 R-3,9-11$ & 590.13 & Rhodochrosite & -8.31 & -13.78 & $26.9-42.9$ & $61.2-48.1$ & $9.6-5.3$ & $2.3-2.9$ \\
\hline $37 \mathrm{R}-3,9-11$ & 590.13 & Calcite & -7.88 & -13.78 & 1.0 & 1.2 & 97.8 & 0 \\
\hline $39 \mathrm{R}-3,102-104$ & 610.44 & Rhodochrosite & -8.52 & 17.03 & $43.6-29.9$ & $54.1-65.6$ & $0.3-2.0$ & $2.0-2.5$ \\
\hline $41 \mathrm{R}-3,144-148$ & 629.31 & Rhodochrosite & -11.88 & -18.51 & 35.4 & 59.5 & 2.1 & 3.0 \\
\hline $41 R-4,0-4$ & 629.37 & Rhodochrosite & & & 32.0 & 63.3 & 2.5 & 2.2 \\
\hline $42 R-4,146-149$ & 641.36 & Rhodochrosite & -10.65 & -17.28 & 33.9 & 60.2 & 3.3 & 2.6 \\
\hline $43 R-2,144-146$ & 647.80 & Rhodochrosite & -10.81 & -16.96 & 34.8 & 61.6 & 1.2 & 2.4 \\
\hline $44 \mathrm{R}-1,100-102$ & 655.70 & Rhodochrosite/siderite & & & $62.9-28.0$ & $30.8-61.8$ & $2.7-6.2$ & $3.6-4.0$ \\
\hline $44 R-5,18-20$ & 660.69 & Rhodochrosite & -7.30 & -18.13 & $30.7-1.4$ & $58.7-78.3$ & $7.0-18.4$ & $3.6-1.9$ \\
\hline $46 \mathrm{R}-1,2-4$ & 674.12 & Rhodochrosite & -7.30 & -20.07 & & & & \\
\hline $46 \mathrm{R}-1,2-4$ & 674.12 & Siderite & -11.43 & -21.36 & 50.1 & 28.9 & 10.6 & 10.4 \\
\hline $51 \mathrm{R}-1,4-8$ & 721.94 & Siderite & -10.25 & -22.33 & & & & \\
\hline $51 \mathrm{R}-1,4-8$ & 721.94 & Calcite & -8.88 & -21.92 & 4.2 & 1.8 & 91.7 & 2.3 \\
\hline $51 \mathrm{R}-1,12-15$ & 722.02 & Calcite & -7.85 & -20.74 & 5.6 & 4.2 & 86.9 & 3.3 \\
\hline
\end{tabular}

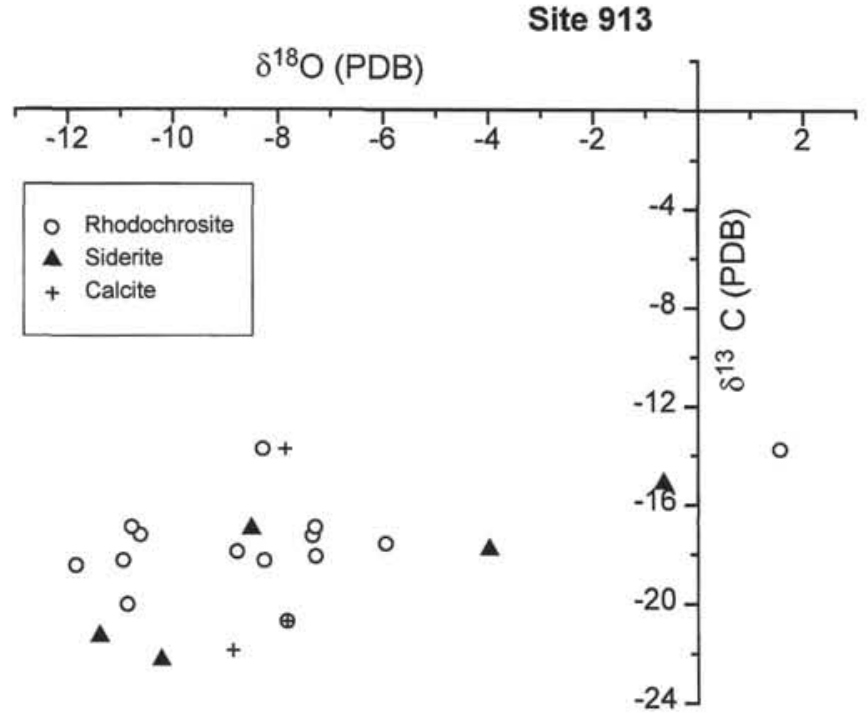

Figure 15. Plot of $\delta^{13} \mathrm{C}$ vs. $\delta^{18} \mathrm{O}$ values (in ppt) for authigenic carbonates from Site 913 .

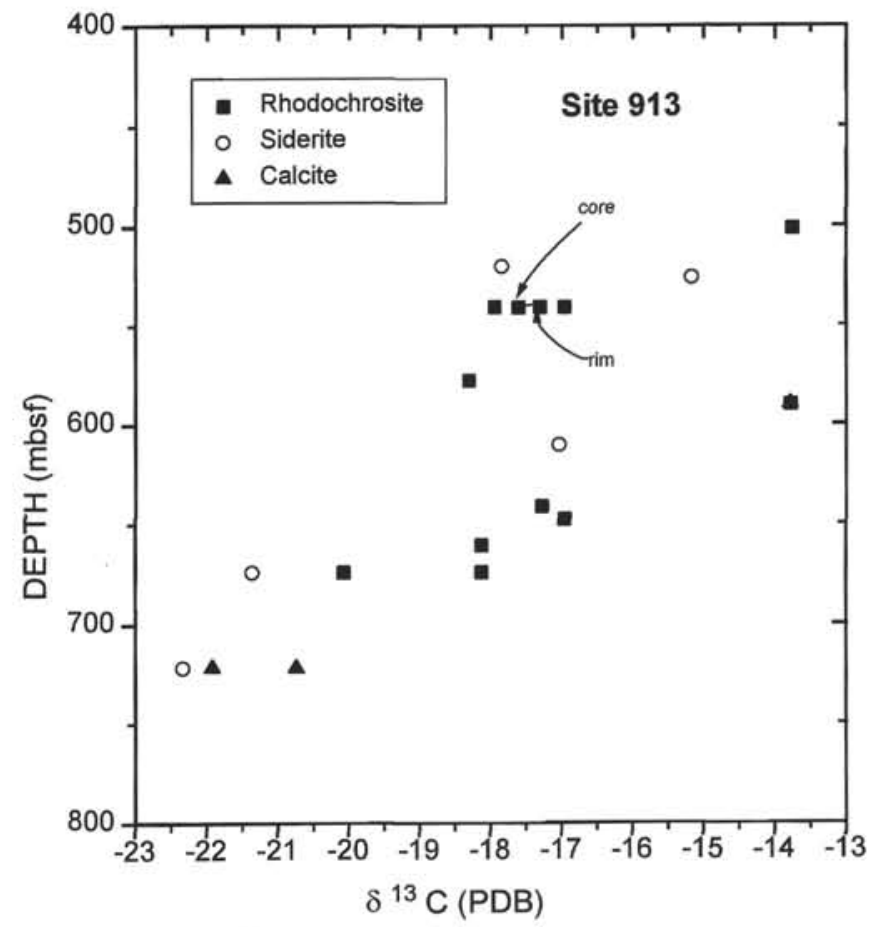

Figure 16. Plot of $\delta^{13} \mathrm{C}$ values (in ppt) vs. depth for authigenic carbonates from Site 913 . 


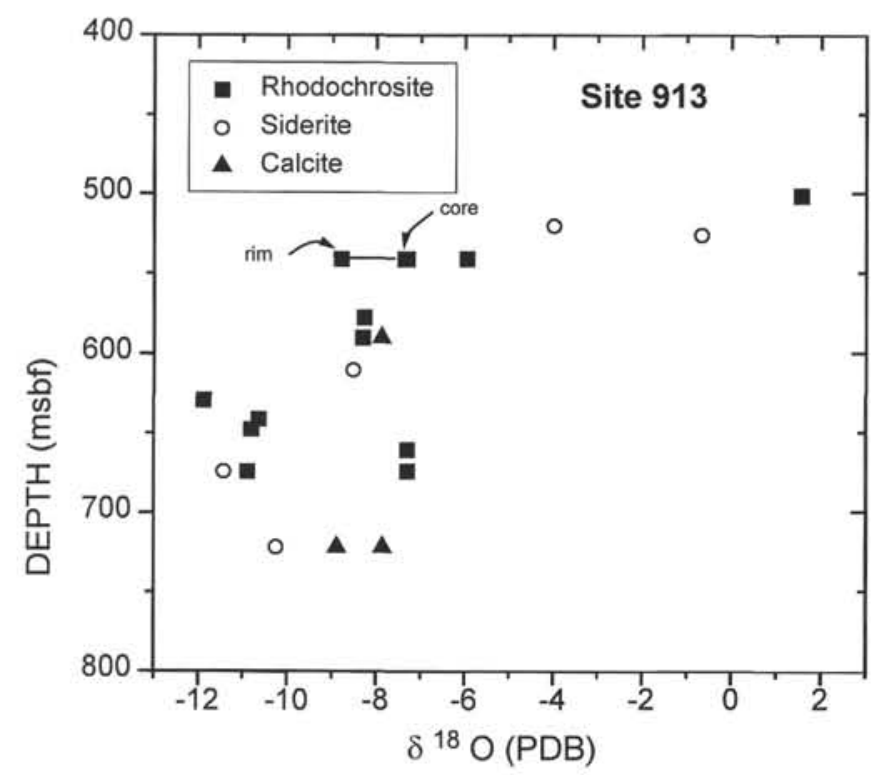

Figure 17. Plot of $\delta^{18} \mathrm{O}$ values (in ppt) vs, depth for authigenic carbonates from Site 913 .

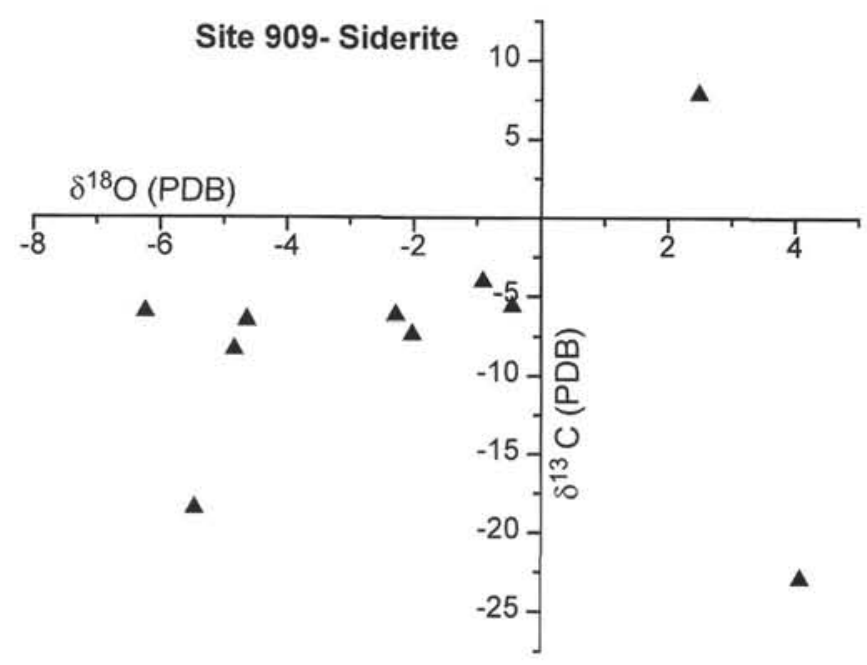

Figure 18. Plot of $\delta^{13} \mathrm{C}$ vs. $\delta^{18} \mathrm{O}$ (in ppt) for siderite from Site 909.

account for the range of observed $\delta^{18} \mathrm{O}$ values. The additional factor is speculated to be sediment-water interaction during shallow burial diagenesis (e.g., Longstaffe, 1989; Land and Prezbindowski, 1981). Alteration of labile volcaniclastic sediment to ${ }^{18} \mathrm{O}$-enriched smectite can shift $\delta^{18} \mathrm{O}$ values of marine pore waters by as much as $-9.5 \%$ SMOW (Lawrence and Gieskes, 1981; Martin, 1993) and produce an increase in $\mathrm{pH}$ (Morad et al., 1996). At Sites 909 and 911, early diagenetic alteration of volcanic glass, dropstones, and micas in the sediments may have contributed to the generation of low- $\delta^{18} \mathrm{O}$ siderites (cf. Mozley and Carothers, 1992; Morad and De Ros, 1994; Morad et al., 1996). Glauconite in sediments at Sites 909 and 911 (Shipboard Scientific Party, 1995b; 1995c) may be evidence for the alteration of volcaniclastics, but further study is required to determine the nature and extent of this alteration and to confirm its role in siderite precipitation.

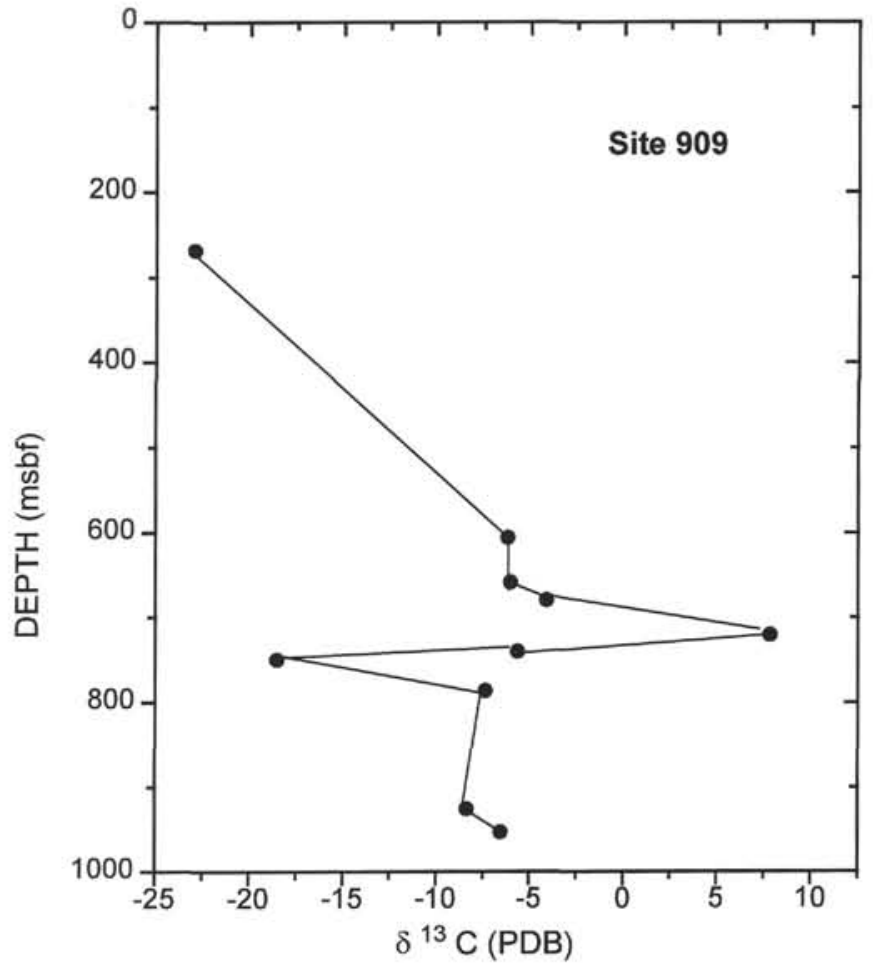

Figure 19. Plot of $\delta^{13} \mathrm{C}$ values (in ppt) vs. depth for siderite from Site 909.

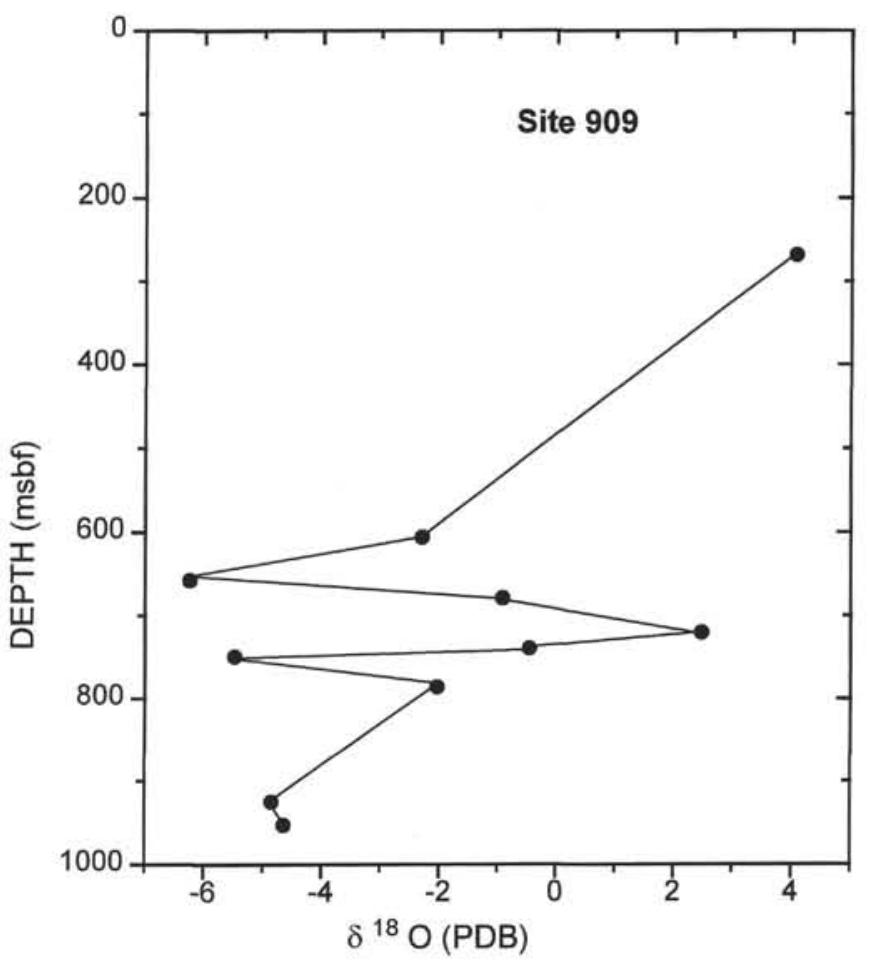

Figure 20. Plot of $\delta^{18} \mathrm{O}$ values (in ppt) vs. depth for siderite from Site 909. 


\section{SUMMARY}

Authigenic carbonates occur in thin layers, nodules, and burrows in fine-grained siliciclastic sediments recovered from Sites 909 (Fram Strait), 911 (Yermak Plateau), and 913 (East Greenland Margin). Siderite, enriched in $\mathrm{Ca}$ and/or $\mathrm{Mg}$, is the predominant carbonate mineral in the sedimentary succession at Sites 909 and 911, whereas ferroan rhodochrosite and manganoan siderite are predominant at Site 913. Pyrite and $\mathrm{Fe}$ monosulfides are commonly associated with these carbonates. Microcrystalline or radial-fibrous calcite and dolomite are minor constituents at these three sites.

Very fine to fine-crystalline siderite from Sites 909 and 911 occurs as interparticle cement, in irregular patches, or as disseminated crystals in the mud matrix. Microcrystalline siderite also comprises rounded intraclasts, up to $250 \mu \mathrm{m}$ in diameter. The $\delta^{13} \mathrm{C}$ values of most siderites from Site 909 are close to $-6 \%$, which suggests an origin in the Fe-reduction, suboxic zone, possibly only centimeters or decimeters below the seafloor. However, minor occurrences of siderite with very low $\delta^{13} \mathrm{C}$ values $(-21.8 \%,-18.5 \%)$ and their close association with authigenic pyrite indicate additional derivation of dissolved carbon from the oxidation of marine organic matter in the bacterial sulfate-reduction zone and during the early stages of methanogenesis. The importance of anaerobic microbial processes is further corroborated by the moderate to high organic matter content and methane concentration at Site 909. The range of $\delta^{18} \mathrm{O}$ values for siderite from Sites 909 and $911(-10.3$ to $+5.1 \%)$ appears to be related to both increasing burial temperatures and sediment-water interaction (e.g., between labile volcaniclastic grains and marine pore waters).

Rhodochrosite microspherules and rhombohedrons have grown displacively within the host sediments at Site 913, largely at shallowburial depths during early diagenesis. The microspherules are concentrically zoned, ideally consisting of a brown, microcrystalline and/or radial-fibrous core, which may be locally pyritic, and a colorless, radial-fibrous or radial-prismatic rim. Rare microspherules have rims that are partly or completely manganoan siderite. Microspherules comprising the inner part of carbonate-rich layers or nodules tend to be large and undistorted, whereas those near the margin of the layer or nodule tend to be smaller (no or little core) and distorted. Rhombohedrons occur as interparticle cement between microspherules, disseminated throughout the mud matrix or comprising the rim of some microspherules. Barite is commonly associated with rhodochrosite, partially or completely filling fractures and voids.

All authigenic carbonates (rhodochrosite, siderite, and calcite) from Site 913 are strongly enriched in ${ }^{12} \mathrm{C}\left(\delta^{13} \mathrm{C}=-22.9\right.$ to $-13.8 \%$ ) and show decreasing $\delta^{13} \mathrm{C}$ values with depth below the seafloor. This evidence, along with authigenic pyrite in microspherule cores, suggests derivation of dissolved carbon from bacterial sulfate-reduction and the early stages of methanogenesis. However, low organic matter content and headspace methane concentrations suggest that dissolved carbon may also have been derived from thermogenic methane. The very low $\delta^{18} \mathrm{O}$ values $(-11.8 \%$ ) for rhodochrosite and the close association with barite in fractures and voids suggest rhodochrosite precipitation from Mn-charged, hydrothermal fluids, possibly related to volcanic activity associated with seafloor spreading.

\section{ACKNOWLEDGMENTS}

This research was supported by grants from the Natural Sciences and Engineering Research Council to N. Chow and I.S. Al-Aasm, a grant from the University of Manitoba to N. Chow, and a grant from the Swedish Natural Science Research Council to S. Morad. This paper has benefited from constructive reviews by M. Coniglio and G.R. Dix.

\section{REFERENCES}

Aagaard, P., Egeberg, P.K., and Smalley, P.C., 1989. Diagenetic reactions in Leg 104 sediments inferred from isotope and major element chemistry of interstitial waters. In Eldholm, O., Thiede, J., Taylor, E., et al., Proc. ODP, Sci. Results, 104: College Station, TX (Ocean Drilling Program), 273-280.

Al-Aasm, I.S., and Blaise, B., 1991. Interaction between hemipelagic sediment and a hydrothermal system: Middle Valley, northern Juan de Fuca Ridge, subarctic northeast Pacific. Mar. Geol., 98:25-40.

Al-Aasm, I.S., Taylor, B.E., and South, B., 1990. Stable isotope analysis of multiple carbonate samples using selective acid extraction. Chem. Geol., $80: 119-125$.

Baker, P.A., Cross, S.L., and Burns, S.J., 1994. Geochemistry of carbonate nodules and cements and implications for hydrothermal circulation, Middle Valley, Juan de Fuca Ridge. In Mottl, M.J., Davis, E.E., Fisher, A.T., and Slack, J.F. (Eds.), Proc. ODP, Sci. Results, 139: College Station, TX (Ocean Drilling Program), 313-328.

Berner, R.A., 1981. A new geochemical classification of sedimentary environments. J. Sediment. Petrol., 51:359-365.

Bohrmann, G., and Thiede, J., 1989. Diagenesis in Eocene claystones, ODP Site 647, Labrador Sea: formation of complex authigenic carbonates, smectites, and apatite. In Srivastava, S.P., Arthur, M.A., Clement, B., et al., Proc. ODP, Sci. Results, 105: College Station, TX (Ocean Drilling Program), 137-154.

Carothers, W.W., Adami, L.H., and Rosenbauer, R.J., 1988. Experimental oxygen isotope fractionation between siderite-water and phosphoric acidliberated $\mathrm{CO}_{2}$-siderite. Geochim. Cosmochim. Acta, 52:2445-2450.

Claypool, G.E., and Kaplan, I.R., 1974. The origin and distribution of methane in marine sediments. In Kaplan, I.R. (Ed.), Natural Gases in Marine Sediments: New York (Plenum), 99-139.

Coleman, M.L., Fleet, A.J., and Donson, P., 1982. Preliminary studies of manganese-rich carbonate nodules from Leg 68, Site 503, eastern equatorial Pacific. In Prell, W.L., Gardner, J.V., et al., Init. Repts. DSDP, 68: Washington (U.S. Govt. Printing Office), 481-489.

Crane, K., Eldholm, O., Myhre, A.M., and Sundvor, E., 1982. Thermal implications for the evolution of the Spitsbergen transform fault. Tectonophysics, 89:1-32.

Dean, W.E., 1974. Determination of carbonate and organic matter in calcareous sediments and sedimentary rocks by loss on ignition. J. Sediment. Petrol., 44:242-248.

Deer, W.A., Howie, R.A., and Zussman, J., 1992. An Introduction to the Rock Forming Minerals: Essex, England (Longman Scientific).

Emery, D., Hudson, J.D., Marshall, J.D., and Dickson, J.A.D., 1988. The origin of late spar cements in the Lincolnshire Limestone, Jurassic of central England. J. Geol. Soc. London, 145:621-633.

Fournier, R.O., 1985. Continental scientific drilling to investigate brine evolution and fluid circulation in active hydrothermal systems. In Raleigh. C.B. (Ed.), Observation of the Continental Crust Through Drilling I: Berlin (Springer-Verlag), 98-122.

Friedman, I., and O'Neil, J.R., 1977. Compilation of stable isotope fractionation factors of geochemical interest. In Fleischer, M. (Ed.), Data of Geochemistry (6th ed.). Geol. Surv. Prof. Pap. U.S., 440-KK:1-12.

Froelich, P.N., Klinkhammer, G.P., Bender, M.L., Luedtke, N.A., Heath, G.R., Cullen, D., Dauphin, P., Hammond, D., Hartman, B., and Maynard, V., 1979. Early oxidation of organic matter in pelagic sediments of the eastern equatorial Atlantic: suboxic diagenesis. Geochim. Cosmochim. Acta, 43:1075-1090.

Gianelli, G., and Teklemarian, M., 1993. Water-rock interaction processes in the Aluto-Langano geothermal field (Ethiopia). J. Volcanol. Geotherm. Res., 56:429-445.

Hattori, K., and Sakai, H., 1980. Meteoric hydrothermal origin of calcites in "Green Tuff' Formations, Miocene age, Japan. Contrib. Mineral. Petrol. $73: 145-150$.

Henrich, R., 1989. Diagenetic environments of authigenic carbonates and opal-CT crystallization in Lower Miocene to Upper Oligocene deposits of the Norwegian Sea (ODP Site 643, Leg 104). In Eldholm, O., Thiede, J., Taylor, E., et al., Proc. ODP, Sci. Results, 104: College Station, TX (Ocean Drilling Program), 233-247.

Irwin, H., Curtis, C.D., and Coleman, M.L., 1977. Isotopic evidence for the source of diagenetic carbonates formed during burial of organic-rich sediments. Nature, 269:209-213.

Kelts, K., and McKenzie, J.A., 1982. Diagenetic dolomite formation in Quaternary anoxic diatomaceous muds of Deep Sea Drilling Project Leg 64, 
Gulf of California. In Curray, J.R., Moore, D.G., et al., Init. Repts. DSDP 64 (Pt. 2): Washington (U.S. Govt. Printing Office), 553-569.

Land, L.S., and Prezbindowski, D.R., 1981. Origin and evolution of saline formation water, Lower Cretaceous carbonates, south central Texas, U.S.A. J. Hydrol., 54:51-74.

Lawrence, J.R., and Gieskes, J.M., 1981. Constraints on water transport and alteration in the oceanic crust from the isotopic composition of pore water. J. Geophys. Res., 86:7924-7934.

Longstaffe, F., 1989. Stable isotopes as tracers in clastic diagenesis. In Hutcheon, I.E. (Ed.), Short Course in Burial Diagnesis. Mineral. Assoc. Can., 201-277.

MacKay, J.L., Longstaffe, F.J., and Plint, A.G., 1995. Early diagenesis and its relationship to depositional environment and relative sea-level fluctuations (Upper Cretaceous Marshybank Formation, Alberta and British Columbia). Sedimentology, 42:161-190.

Martin, J.B., 1993. Origins and compositions of fluids at convergent margins [Ph.D. dissert.]. Univ. of California, San Diego.

Matsumoto, R., 1992. Diagenetic dolomite, calcite, rhodochrosite, magnesite, and lansfordite from Site 799, Japan Sea-implications for depositional environments and the diagenesis of organic-rich sediments. In Gradstein, F.M., Ludden, J.N., et al., Proc. ODP, Sci. Results, 127/128 (Pt. 1): College Station, TX (Ocean Drilling Program), 75-98.

Matsumoto, R., and Matsuhisa, Y., 1985. Chemistry, carbon and oxygen isotope ratios, and origin of deep-sea carbonates at Sites 438, 439, and 584: inner slope of the Japan Trench. In Kagami, H., Karig, D.E., and Coulburn, W.T., Init. Repts. DSDP, 87: Washington (U.S. Govt. Printing Office), 669-678.

McArthur, J.M., Benmore, R.A., Coleman, M.L., Soldi, C., Yeh, H.-W., and O'Brien, G.W., 1986. Stable isotopic characterization of francolite formation. Earth Planet. Sci. Lett., 77:20-34.

McCorkle, D.C., and Emerson, S.R., 1988. The relationship between porewater carbon isotopic composition and bottom water oxygen composition. Geochim. Cosmochim. Acta, 52:1169-1178.

McCrea, J.M., 1950. On the isotopic chemistry of carbonates and a paleotemperature scale. J. Chem. Phys., 18:849-857.

Morad, S., and De Ros, L.F., 1994. Geochemistry and diagenesis of stratabound calcite cement layers within the Rannoch Formation of the Brent Group, Murchison Field, North Viking Graben (north North Sea)-discussion. Sediment. Geol., 93:135-141.

Morad, S., De Ros, L.F., and Al-Aasm, I.S., 1996. Origin of low $\delta^{18} \mathrm{O}$, precompactional ferroan carbonates in the marine Stø Formation (Middle Jurassic), offshore NW Norway. Mar. Pet. Geol.,13:263-276.

Mozley, P., and Carothers, W.W., 1992. Elemental and isotopic composition of siderite in the Kuparuk Formation, Alaska: effect of microbial activity and water/sediment interaction on early pore-water chemistry. J. Sediment. Petrol., 62:681-692.

Myhre, A.M., and Thiede, J., 1995. North Atlantic-Arctic Gateways. In Myhre, A.M., Thiede, J., Firth, J.V., et al., Proc. ODP, Init. Repts., 151: College Station, TX (Ocean Drilling Program), 5-26.
Pisciotto, K.A., and Mahoney, J.J., 1981. Isotopic survey of diagenetic carbonates, Deep Sea Drilling Project, Leg 63. In Yeats, R.S., Haq., B.U., et al., Init. Repts. DSDP, 63: Washington (U.S. Govt. Printing Office), 595609

Ritger, S., Carson, B., and Suess, E., 1987. Methane-derived authigenic carbonates formed by subduction-induced pore water expulsion along the Oregon/Washington margin. Geol. Soc. Am. Bull., 98:147-156.

Rosenbaum, J.M., and Sheppard, S.M.F., 1986. An isotopic study of siderite, dolomite and ankerite at high temperatures. Geochim. Cosmochim. Acta, 50:1147-1150.

Sass, E., Bein, A., and Almogi-Labin, A., 1991. Oxygen isotope composition of diagenetic calcite in organic-rich rocks: evidence for ${ }^{18} \mathrm{O}$ depletion in marine anaerobic pore water. Geology, 19:839-842.

Shipboard Scientific Party, 1995a. Explanatory notes. In Myhre, A.M., Thiede, J., Firth, J.V., et al., Proc. ODP, Init. Repts., 151: College Station, TX (Ocean Drilling Program), 27-45.

, 1995b. Site 909. In Myhre, A.M., Thiede, J., Firth, J.V., et al., Proc. ODP, Init. Repts., 151: College Station, TX (Ocean Drilling Program), 159-220.

1995c. Site 911. In Myhre, A.M., Thiede, J., Firth, J.V., et al., Proc. ODP, Init. Repts., 151: College Station, TX (Ocean Drilling Program), 271-318.

, 1995d. Site 913. In Myhre, A.M., Thiede, J., Firth, J.V., et al., Proc. ODP, Init. Repts., 151: College Station, TX (Ocean Drilling Program), 345-382.

Thiede, J., Myhre, A.M., Firth, J.V., and the Shipboard Scientific Party, 1995. Cenozoic Northern Hemisphere polar and subpolar ocean paleoenvironments (Summary of ODP Leg 151 drilling results). In Myhre, A.M., Thiede, J., Firth, J.V., et al., Proc, ODP, Init. Repts., 151: College Station, TX (Ocean Drilling Program), 397-420.

von Rad, U., and Botz, R., 1987. Diagenetic Fe-Mn carbonates in the Cretaceous and Tertiary continental rise sediments of DSDP Sites 603 off the eastern U.S.A. In van Hinte, J.E., Wise, S.W., Jr., et al., Init. Repts. DSDP, 93: Washington (U.S. Govt. Printing Office), 1061-1077.

Vrolijk, P., and Sheppard, S.M.F., 1991. Syntectonic carbonate veins from the Barbados accretionary prism (ODP Leg 110): record of paleohydrology. Sedimentology, 38:671-690.

Whiticar, M.J., and Faber, E., 1986. Methane oxidation in marine and limnic sediments and water columns. 12th Intl. Mtg. Organic Geochem. 1985, Juelich. In Leythaeuser, D., and Rullkötter, J. (Eds.), Advances in Organic Geochemistry (Vol. 10): New York, (Springer-Verlag), 759-768.

Zheng, Y.-F., and Hoefs, J., 1993. Carbon and oxygen isotopic covariations in hydrothermal calcites. Miner. Deposit., 28:79-89.

Date of initial receipt: 1 July 1995

Date of acceptance: 30 December 1995

Ms 151SR-145 

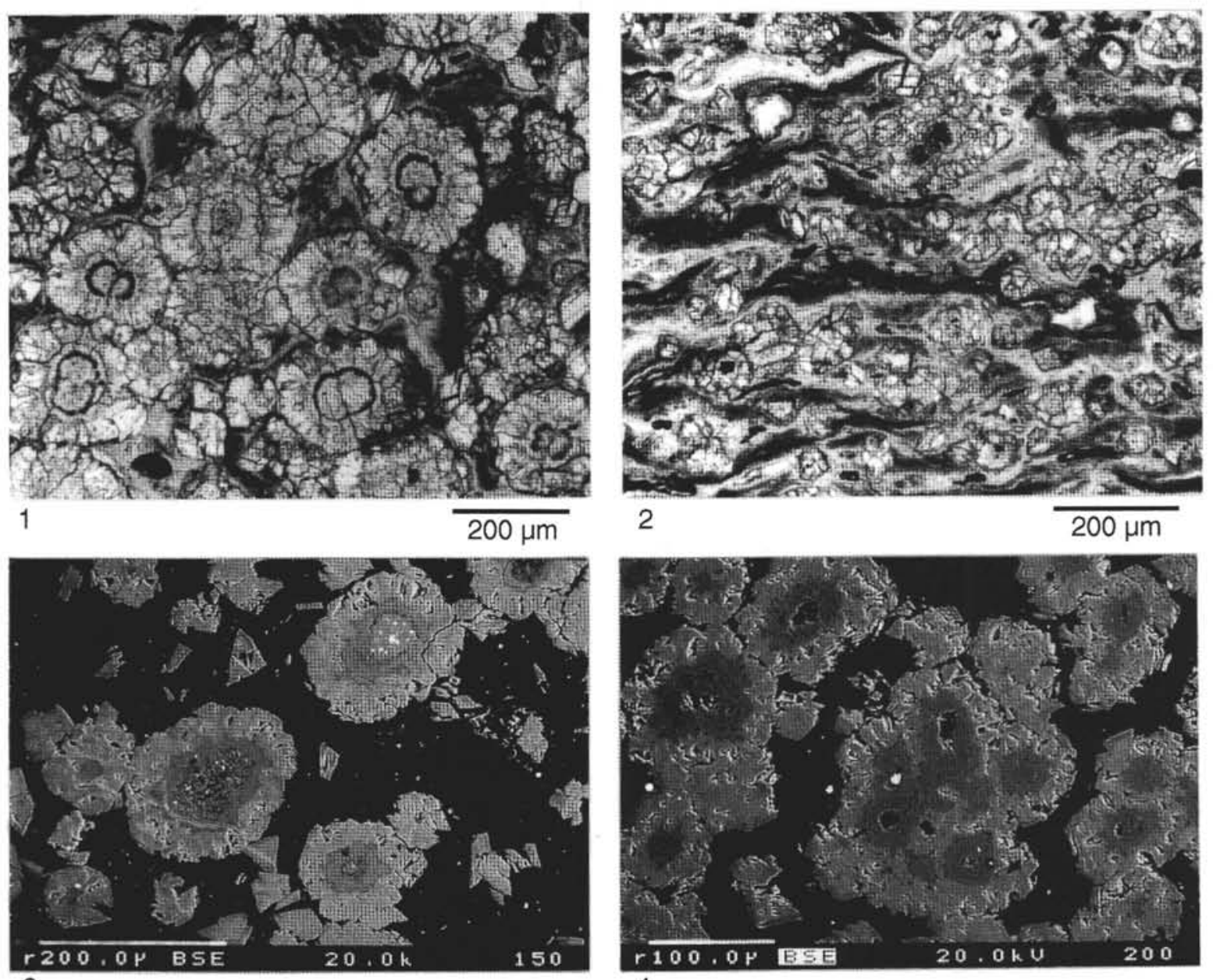

3

4

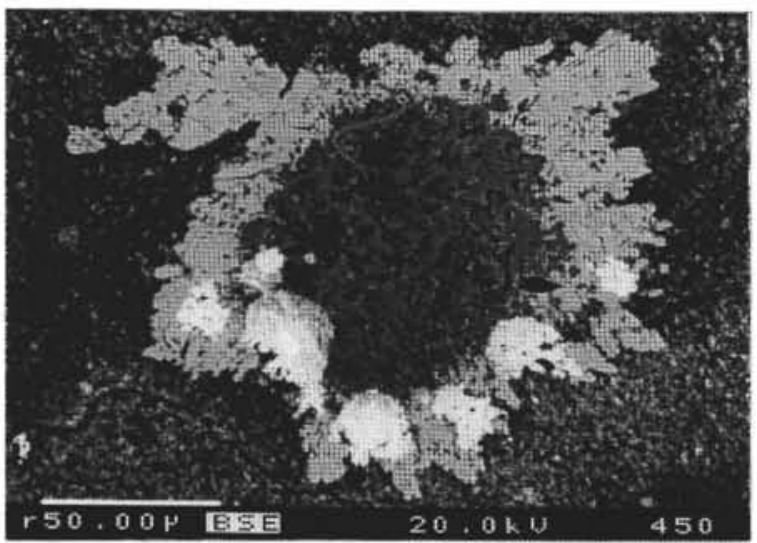

5

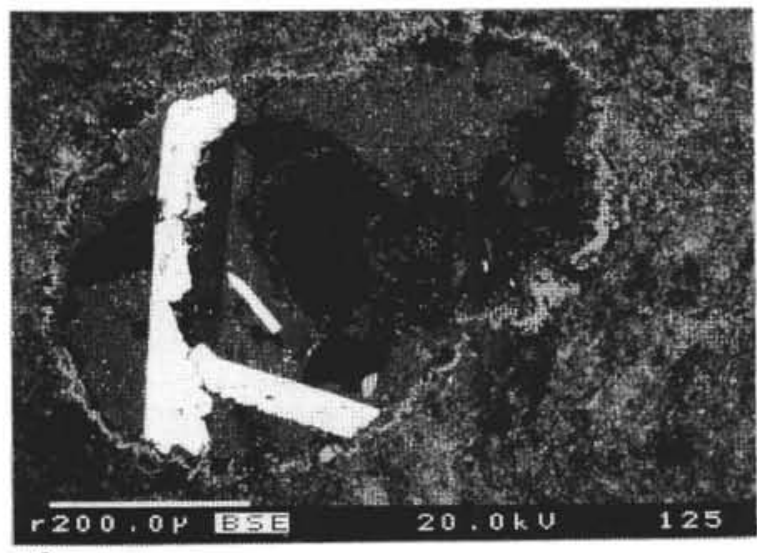

6

Plate 1. Rhodochrosite microspherules from Site 913. 1. Concentrically zoned rhodochrosite microspherules and euhedral rhombohedrons in the middle of a carbonate-rich layer. Plane-polarized light photomicrograph, Sample 151-913B-42R-4, 146-149 cm. 2. Distorted rhodochrosite microspherules and rhombohedrons at the margin of the carbonate-rich layer in Figure 1. Plane-polarized light photomicrograph. 3. BSE photomicrograph of rhodochrosite microspherules from the same sample as in Figure 1. The core and rim (medium gray and light gray, respectively, in photograph) are of similar composition (core: $\sim \mathrm{Mn}_{59.1} \mathrm{Fe}_{32.1} \mathrm{Ca}_{4,7} \mathrm{Mg}_{2.9} ;$ rim: $\sim \mathrm{Mn}_{59.5} \mathrm{Fe}_{35.3} \mathrm{Ca}_{1.1} \mathrm{Mg}_{2.2}$ ). Clay matrix is black in photograph. 4. Rhodochrosite microspherules with cores (dark gray in photograph) more enriched in $\mathrm{Ca}$ and $\mathrm{Mg}$ than the rims (light gray in photograph); core: $\sim \mathrm{Mn}_{55.9} \mathrm{Fe}_{25.8} \mathrm{Ca}_{11.9} \mathrm{Mg}_{4.3}$; rim: $\sim \mathrm{Mn}_{59.3} \mathrm{Fe}_{34.3} \mathrm{Ca}_{1.9} \mathrm{Mg}_{2.8}$. Clay matrix is black in photograph. BSE photomicrograph, Sample 151-913B-44R-5, 18-20 cm. 5. Microspherule composed of a rhodochrosite rim (light gray in photograph) and silica core (dark gray in photograph) in a clay matrix (speckled medium gray in photograph). White blebs are pyrite. BSE photomicrograph, Sample 151-913B$30 \mathrm{R}-1,102-104 \mathrm{~cm}$. 6. Microspherule composed of a rhodochrosite rim (white in photograph) and partially eroded clay core (void space is black and clay is dark gray in photograph) in a silty clay matrix. Barite crystals (white in photograph) partially fill the core. BSE photomicrograph, Sample 151-913B-37R-3, 9$11 \mathrm{~cm}$. 


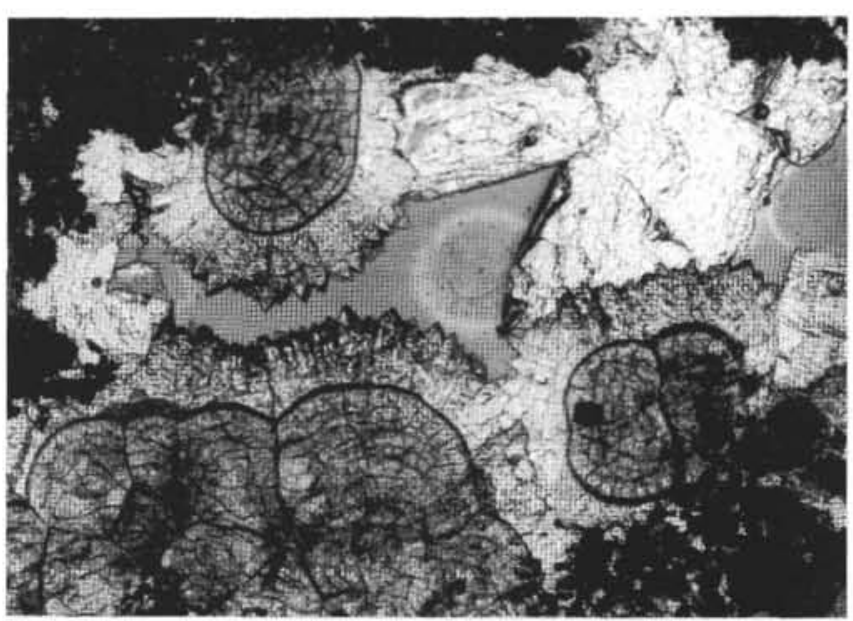

1

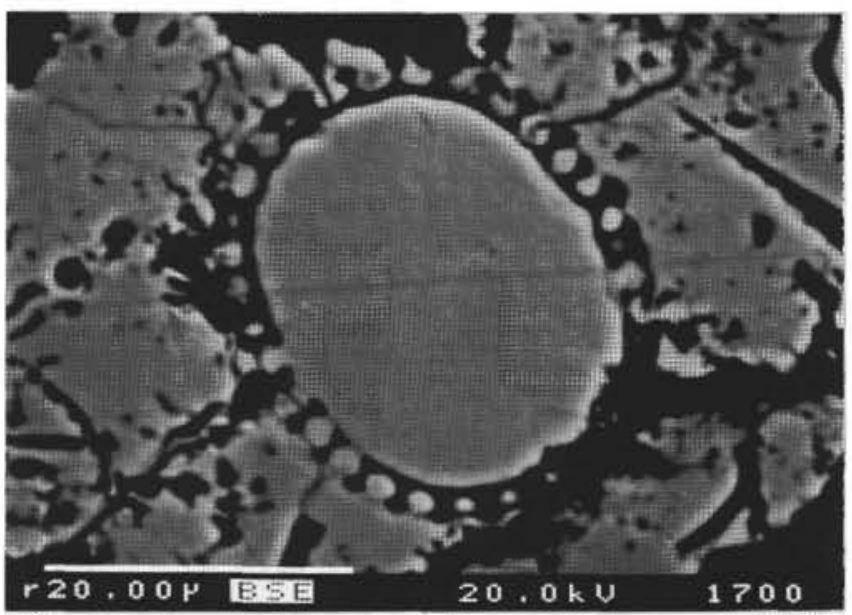

3

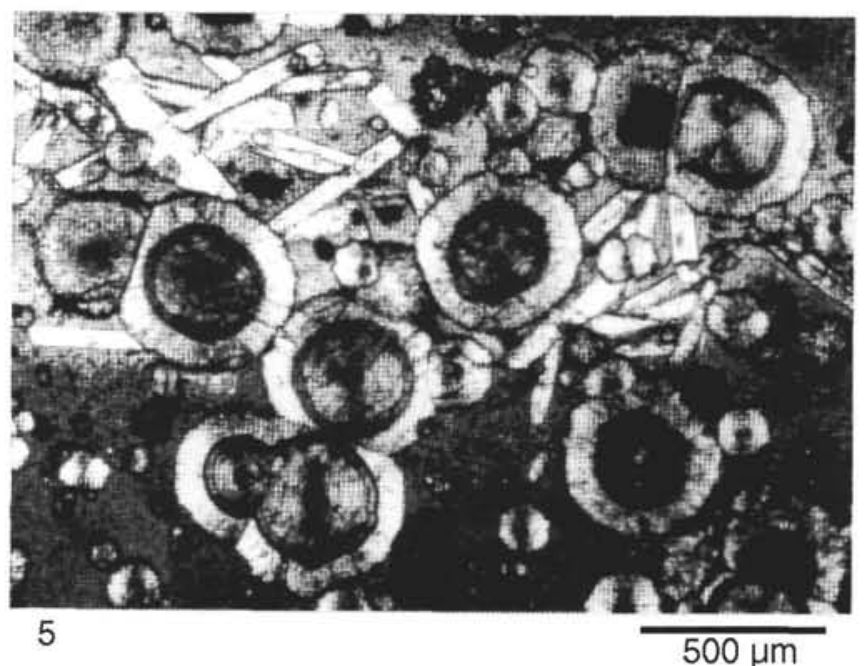

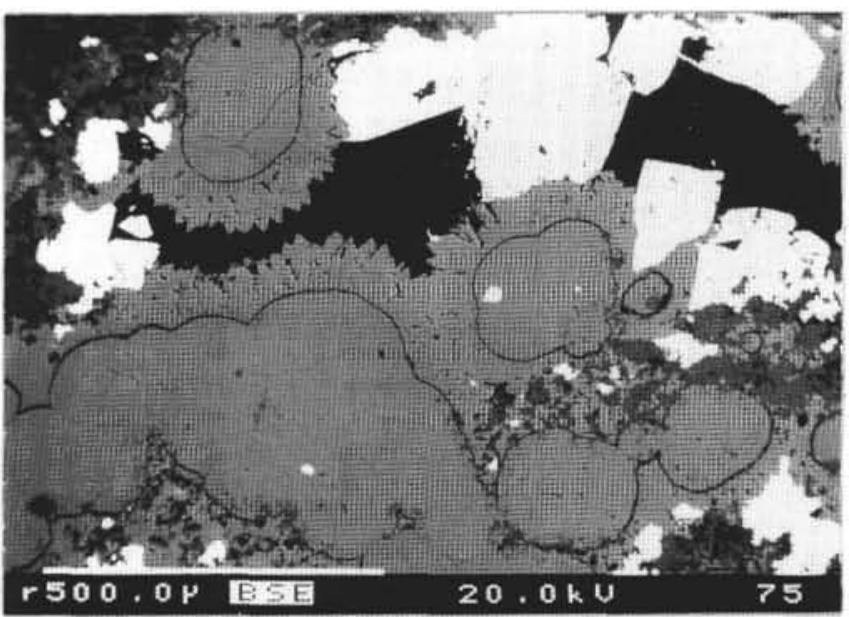

2

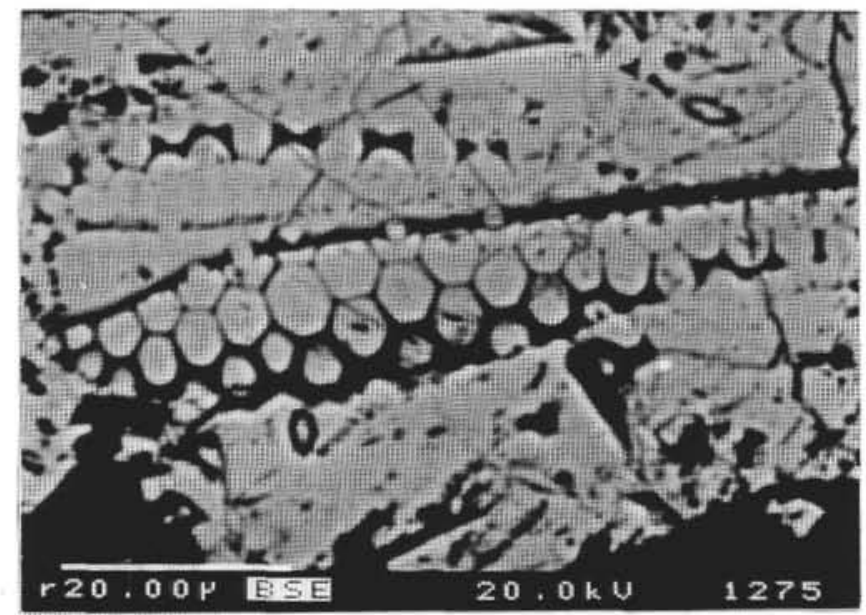

4

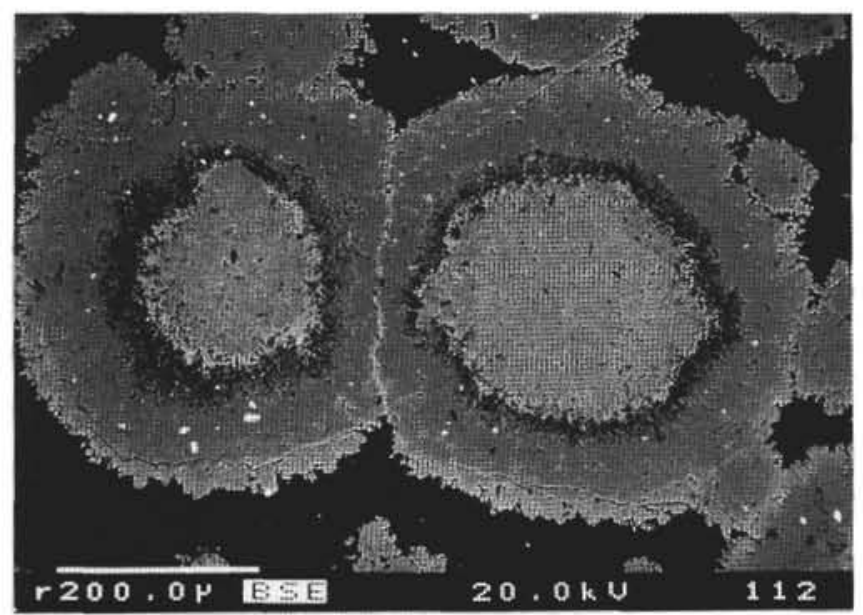

6

Plate 2. Rhodochrosite microspherules from Site 913. 1. Collomorphic rhodochrosite (medium gray in photograph) rimmed by isopachous, radial-fibrous rhodochrosite (light gray in photograph). Barite crystals (upper right in photograph) partially fill remaining pore space. Plane-polarized light photomicrograph, Sample 151-913B-36R-1, 47-49 cm. 2. BSE photomicrograph of Figure 1 (rhodochrosite $=$ gray, barite $=$ white, black $=$ voids in photograph). 3, 4. Diatoms replaced by rhodochrosite. BSE photomicrograph, Sample 151-913B-28R-1, 107-108 cm. 5. Rhodochrosite microspherules replacing Bolboforma. Elongated barite crystals are scattered through the clay matrix (upper half of photograph). Plane-polarized light photomicrograph, Sample 151-913B-31R-2, 27-31 cm. 6. BSE photomicrograph of microspherules from same sample as in Figure 5. Outer margin of core (black ring in photograph) has been partially dissolved. 

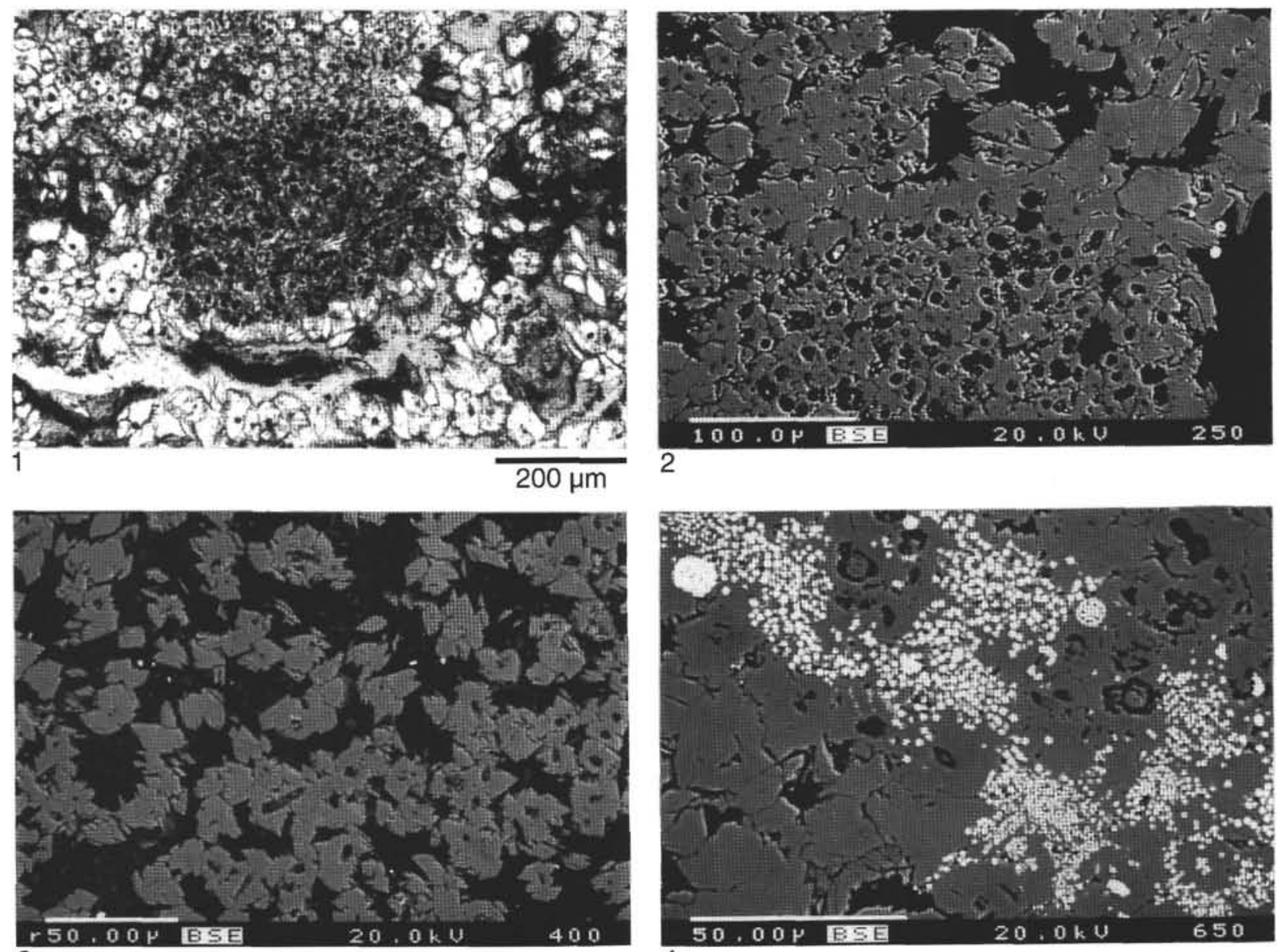

3

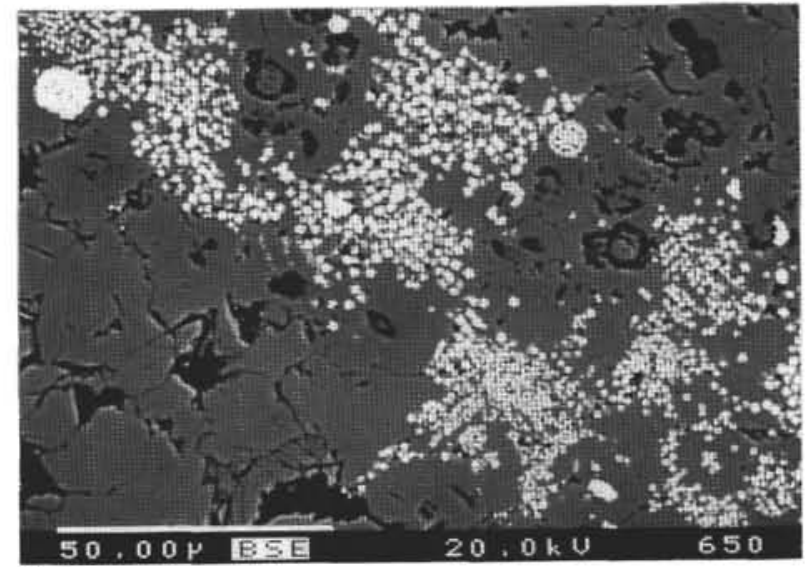

4
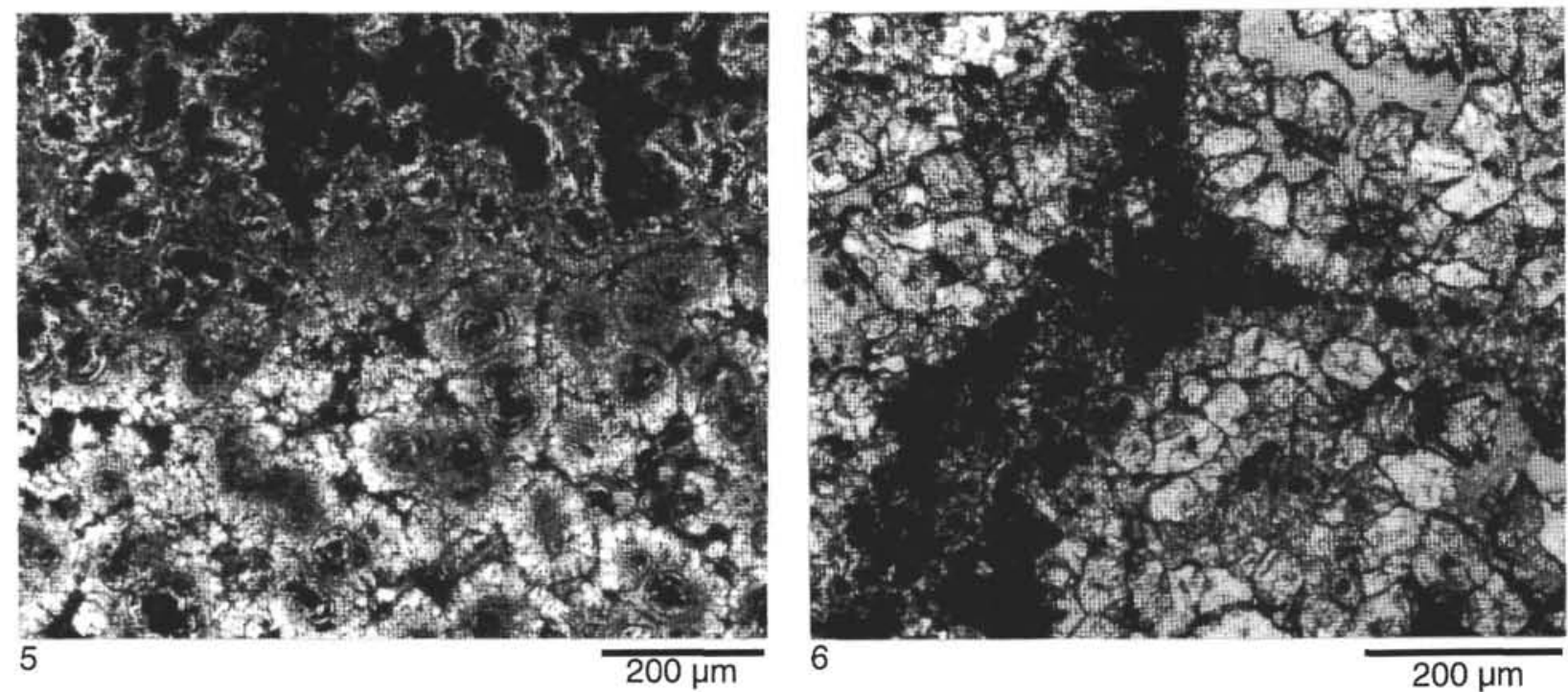

Plate 3. Rhodochrosite rhombohedrons and microspherules from Site 913. 1. Rhodochrosite rhombohedrons in a clay matrix. A relict burrow structure(?) is preserved by dark brown cores of the rhombohedrons (center of photograph). Plane-polarized light photomicrograph, Sample 151-913B-41R-4, 0-4 cm. 2. BSE photomicrograph of same sample as in Figure 1 (rhodochrosite $=$ gray; clay matrix = black). 3. Rhodochrosite rhombohedrons (medium gray in photograph) showing zoning (core: $\sim \mathrm{Mn}_{57.8} \mathrm{Fe}_{36.9} \mathrm{Ca}_{0.6} \mathrm{Mg}_{2}$; rim: $\sim \mathrm{Mn}_{53.1} \mathrm{Fe}_{42.8} \mathrm{Ca}_{0.3} \mathrm{Mg}_{1.9}$ ) in clay matrix (dark gray in photograph). BSE photomicrograph, Sample 151913B-39R-3, 102-104 cm. 4. Rhodochrosite rhombohedrons (gray in photograph) with disseminated pyrite (white in photograph). BSE photomicrograph, Sample 151-913B-43R-2, 144-146 cm. 5. Carbonate-rich layer composed of alternating laminae of dense, irregularly shaped microspherules (upper half of photograph) and laminae of larger microspherules with clear rims (lower half of photograph). Plane-polarized light photomicrograph, Sample 151-913B-44R-5, 18$20 \mathrm{~cm}$. 6. Pelleted Zoophycos burrow replaced by small microspherules (black in photograph) and rhombohedrons (light gray in photograph) of rhodochrosite. Plane-polarized light photomicrograph, Sample 151-913B-32R-2, 74-78 cm (see Fig. 6 for core photograph). 


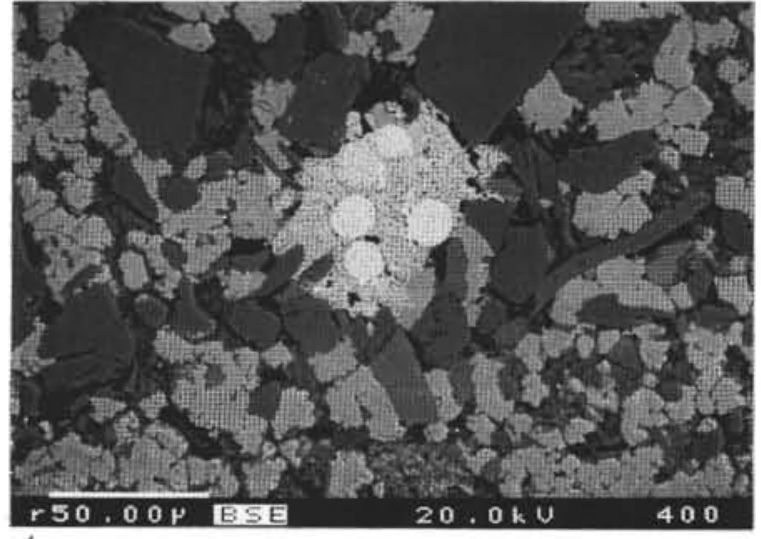

1

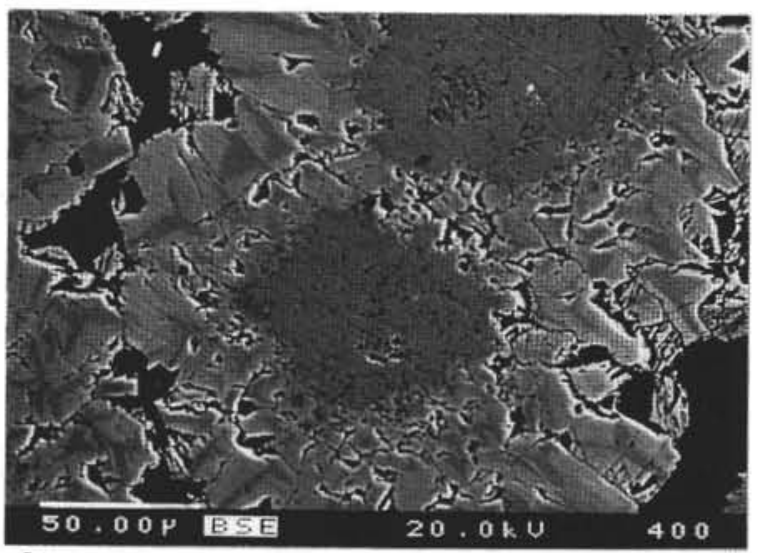

3

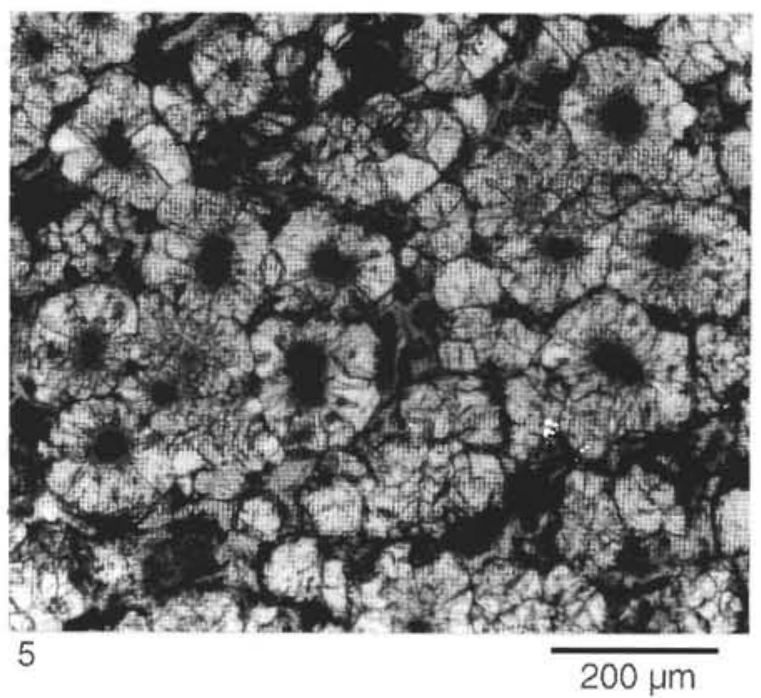

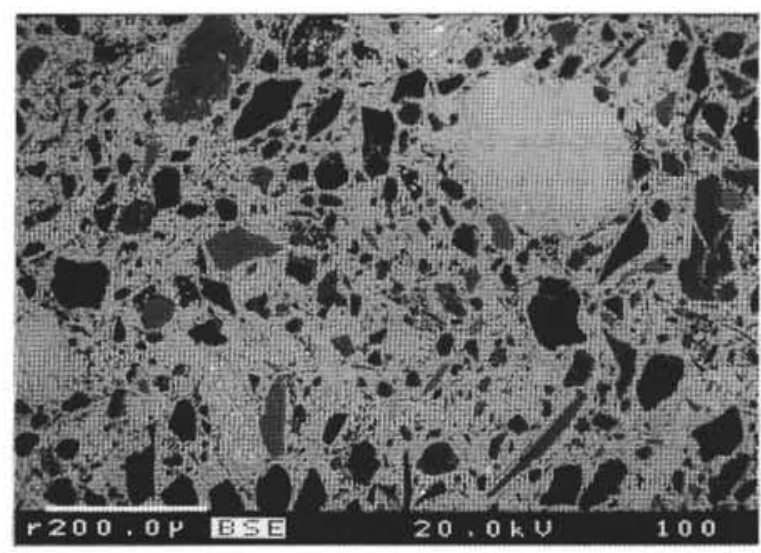

2
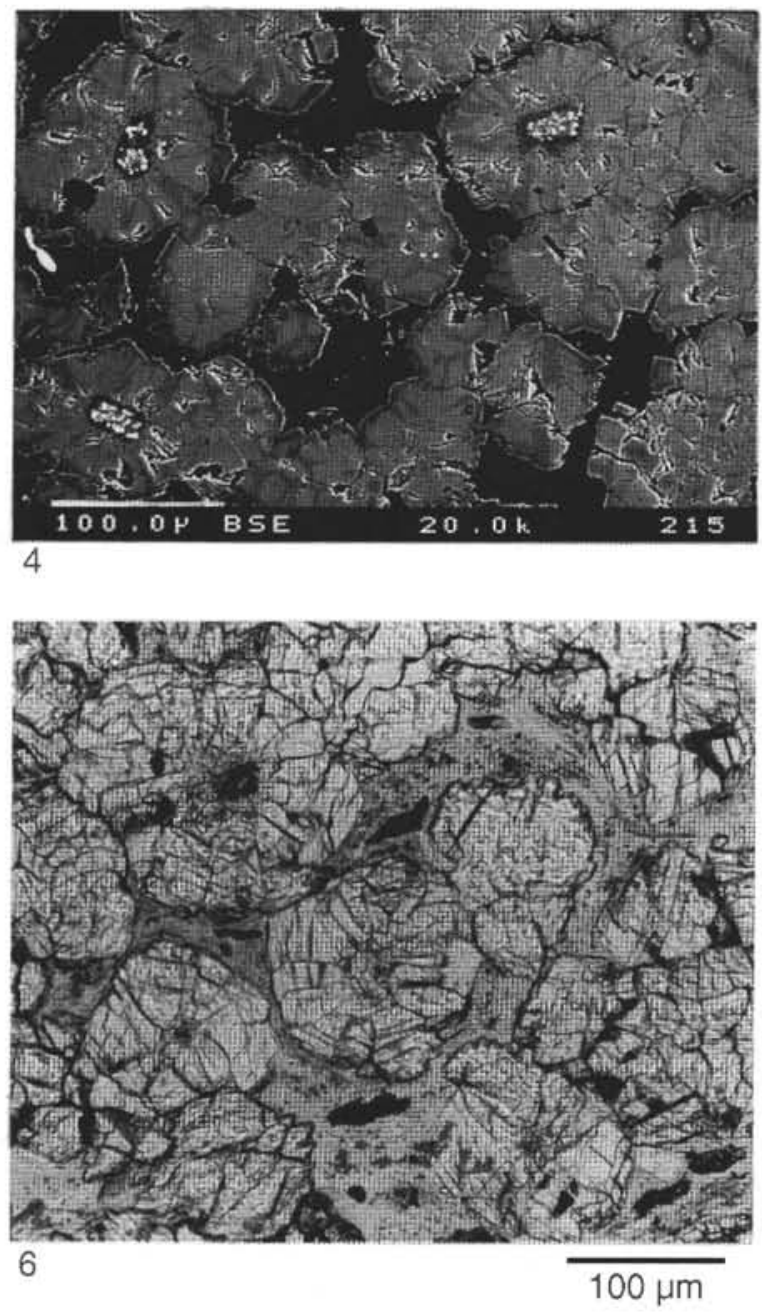

Plate 4. Siderite from Sites 909 and 913. 1. Siderite cement (light gray in photograph) in siltstone (siliciclastic grains = dark gray in photograph). Pyrite crystals and framboids are common (white areas in center of photograph). BSE photomicrograph, Sample 151-909C-70R-1, 28-30 cm. 2. Rounded siderite intraclast (upper right quarter of photograph) and siderite cement (light gray in photograph) in siltstone (siliciclastic grains = dark and medium gray in photograph). BSE photomicrograph, Sample 151-909C-88R-2, 57-59 cm. 3. Microspherules with rhodochrosite core $\left(\sim \mathrm{Mn}_{60.9} \mathrm{Fe}_{27.6} \mathrm{Ca}_{6.2} \mathrm{Mg}_{3.9}\right.$, medium gray in photograph) and siderite rim ( $\sim \mathrm{Fe}_{63.5} \mathrm{Mn}_{32.9} \mathrm{Ca}_{0.4} \mathrm{Mg}_{2.4}$, light gray in photograph; $\sim \mathrm{Fe}_{61.9} \mathrm{Mn}_{28.6} \mathrm{Ca}_{5.1} \mathrm{Mg}_{4.7}$, medium gray "strips" in photograph). BSE photomicrograph, Sample 151-913B-44R-1, 100-102 cm. 4. Rhodochrosite microspherules $\left(\sim \mathrm{Mn}_{55.8} \mathrm{Fe}_{30.1} \mathrm{Ca}_{7.8} \mathrm{Mg}_{4.0}\right.$, light gray in photograph) with siderite rim and "strips" $\left(\sim \mathrm{Fe}_{49.1} \mathrm{Mn}_{28.3} \mathrm{Ca}_{10.4} \mathrm{Mg}_{10.2}\right.$, medium gray in photograph). BSE photomicrograph, Sample 151-913B-46R-1, $2-4 \mathrm{~cm}$. 5, 6. Plane-polarized light photomicrographs of microspherules in same sample as in Figure 4. Figure 5 is the middle of the carbonate-rich layer; Figure 6 is near the margin of the layer. 